\title{
İzmit Tarihi Yeni Hamam Restorasyon Projesi: Yapısal Değerlendirme
}

\section{Öz}

\author{
Emre KISHALI ${ }^{1 *}$
}

Bu çalışmada Kocaeli, İzmit, Hacıhasan Mahallesi, 396 Ada, 3 Parselde bulunan, 18. yy.'da inşa edilmiş Yeni Hamamın restorasyon projesi kapsamında yapısal davranışı ele alınmıştır. Yapı mimari koruma ve geçirmiş olduğu müdahaleler açısından önemli bir örnektir. Yapının uzun süre işlevsiz kalması, 90'lı yıllarda bitişiğine inşa edilen betonarme yapının hamama etkisi, 1999 yılında deprem geçirmiş olmasından dolayı hasarlı ve atıl olan hamam yapısının yeniden kullanımı için 2016 yılında restorasyon çalışması başlamıştır. 2018 yılında tamamlanan restorasyon çalışması için rölöve, restitüsyon ve restorasyon projeleri Bozdağ Mimarlık tarafından hazırlanmıştır. Kocaeli Üniversitesi Mimarlık ve Tasarım Fakültesi Mimarlık Bölümü Restorasyon Anabilim Dalından hamamın yapısal davranışının değerlendirilmesi üzerine destek istenmiştir ${ }^{2}$. Yeni Hamam Cepheleri için termal kamera görüntüleme testi Schmidt beton test çekici sonuçları ve SAP2000 simülasyon programı kullanılarak oluşturulan analitik model ile analiz sonuçları oluşturulmuştur. Yapının restorasyon öncesi durumunu yansıtan sayısal model, analiz süreci, sonuçları ile restorasyon müdahaleleri anlatılmıştır.

Anahtar kelimeler: Yeni Hamam, restorasyon, koruma mühendisliği, İzmit

\section{The Restoration Project of Izmit Yeni Hamam: Structural Evaluation}

\begin{abstract}
In this study, the structural behaviour of Yeni Hamam, located in block no 396, lot no 3 of Hacıhasan neighborhood, İzmit - Kocaeli was analyzed in the context of restoration project. The structure is an important case considering architectural conservation and the interventions. The hammam which was damaged and obsolete due to being abandoned for a long time, the effect of the adjacent reinforced concrete buildings constructed in 1990s and the 1999 earthquake, was planned to be re-used with a restoration project started in 2016. The architectural survey, restitution and restoration project was prepared by Bozdağ Architecture for the restoration work completed in 2018. The report on structural behavior of the hammam was prepared by Kocaeli University, Faculty of Architecture and Design, Department of Architecture, Restoration Program. Analytic model and its results were generated by using thermal camera captures, Schmidt hammer results and SAP2000 program.
\end{abstract}

Keywords: Yeni Hamam, restoration, conservation engineering, Izmit

\footnotetext{
${ }^{1}$ Kocaeli Üniversitesi, Mimarlık ve Tasarım Fakültesi, Mimarlık Bölümü, Restorasyon ABD.

* İlgili yazar/Corresponding author: emre.kishali@kocaeli.edu.tr

Gönderim Tarihi / Received Date: 15.05.2020

Kabul Tarihi / Accepted Date: 08.06.2020

${ }^{2}$ Bu yayın, Bozdağ Mimarlık tarafından Kocaeli Üniversitesi Mimarlık ve Tasarım Fakültesi Mimarlık Bölümü Restorasyon Anabilim Dalından hamamın yapısal davranışının Kocaeli Kültür Varlıklarını Koruma Bölge Kuruluna değerlendirilmesi üzerine talep edilen çalışmadan üretilmiştir. Hamam'ın restorasyon uygulaması tamamlanmış olup uygulama sırasında danışmanlık yapılmıştır.
} 


\section{GíRiş}

Tarihi yapıların korunması ve bunların gelecek kuşaklara aktarılması, ülkelerin koruma yaklaşımları ve güncel mevzuat ile sağlanmaktadır. Koruma kültürünün oluşmasında tarihi çevreden sorumlu kurumlar kadar alanda yaşayanların yaklaşımları da önemlidir. 21. yy.'dan itibaren tarihi alanlar ile kültürel miras hızlı kentleşme, endüstrileşme, aynılaşma, doğal afetler ve ekonomik gelişmelerin getirdiği değişimler ile baskı altındadır. Bu konuda uluslararası ve ulusal kuruluşlar bu konuda kanun, tüzük ve rehberler hazırlayarak alan paydaşlarına yol göstermektedir. ICOMOS Türkiye Mimari Mirası Koruma Bildirgesi Türkiye'de yer alan kültürel varlıkların korunması için hazırlanmış ulusal bir çerçeve koyması açısından önemli bir yere sahiptir.

Bildirgede mimari mirasın koruma amacı aşağıdaki gibi belirtilmiştir.

“...özgünlüğü ve kimliği oluşturan nitelikleri bozmadan estetik ve kültürel değerleri ortaya çıkarmaktır. Kültürel, sanatsal, teknik ve ustalık gerektiren bir eylem olan mimari koruma, koruma etiğine uygun olarak bilimsel ve sistematik araştırma ve değerlendirmelere dayanan, insanoğlunun kültürel üretimine saygılı bir uygulamadır." (ICOMOS Türkiye, 2013)

İnşa edildiği dönemin ekonomik, teknolojik, sosyo-kültürel değerlerini yansıtan yapı tipleri olarak tanımlayabileceğimiz anıtsal mimarlık örneklerinin korunarak geleceğe aktarılması, toplumsal belleği sürekli kılmaktadır. Ortak geçmişi hatırlatan ve birlikteliği güçlendiren evrensel bir yaklaşım ile bütüncül korumanın önemi bulunmaktadır. Bu bağlamda, deprem bölgesi olarak bilinen Kocaeli'nde geleneksel olarak inşa edilmiş ve kuşaktan kuşağa aktarılarak günümüze kadar ulaşmış anıtsal yapıların estetik ve kültürel değerlerinin gelecek kuşaklara aktarılması açısından önemlidir. Kentte anıtsal yapı örneklerinin bulunduğu ancak birçoğunun yıkıldığı, bir kısmının da kısmi ya da kapsamlı müdahalelere maruz kaldığı incelemeler ve literatür araştırmalarında görülmüştür. Deprem bölgesinde bulunan bu tarihi yapıların, sismik kuvvetler altındaki dayanımı ve bunlara karşı gösterdiği davranış ile ilgili çalışmalar tarihi yapıların korunması ve gelecek kuşaklara aktarılmasında önemli bir yer tutmaktadır.

İzmit kenti Bithynia bölgesinde, Nicomedia adıyla bilinen kent, günümüze kadar Roma, Bizans, Osmanlı ve Cumhuriyet dönemlerinde varlığını sürdürmüştür. Bu süreçte kentin yapısı değişmiş, dönüşmüş ve yeni eklerle ile çok katmanlı bir kent halini almıştır. Kocaeli Kültür Varlıkları Koruma Bölge Kurulu tescil yapı listesi incelendiğinde çok katmanlı yapı kültür varlıklarına da yansımıştır. İzmit ilçesinde yer alan tescilli kültür varlığı listesinin sur kalıntısı, burç, cami, hamam, mektep, çeşme, konut, türbe, mezarlık, antrepo, okul, fabrika, yol kalıntısı, kemer, mezar odası, tümülüs, sütun gibi farklı yapı ve yapı kalıntılarını içerdiği görülmektedir (URL - 1). Öte yandan gerek değişen koşullar ile işlevini kaybeden, gerek Kocaeli toplumsal belleğinde yer etmiş, anı ve sosyal değeri yüksek hamam yapılarının korunması ve geleceğe aktarılması önemlidir. İzmit'te tescilli olarak Orta Hamam, Yalı Hamamı, Küçük Hamam, Yeni Hamam, Pertev Mehmet Paşa Hamamı, Süleyman Paşa Hamamı tescilli olarak bulunmaktadır.

Bu yapılardan Hacıhasan Mahallesi, 396 Ada, 3 Parselde bulunan Yeni Hamam yapısı mimari koruma ve geçirmiş olduğu müdahaleler açısından önemli bir örnek olmaktadır. Bozdağ Mimarlık'tan alınan bilgilere göre yapı, Gayrimenkul Eski Eserler ve Anıtlar Yüksek Kurulu 10.11.1979 tarih ve 11612 sayılı kararı ile tescil edilmiştir. İstanbul 2 Nolu Kültür ve Tabiat Varlıkları Kurulu başkanlığının 20.11.1990 tarih ve 2586 sayılı kararı ile onaylı rölöve ve restorasyon projesi ile parselin boş kalan alanına hamamın 
restorasyonu önkoşulu ile yapı izni verilmiştir (Bozdağ, 2015b). Yapının uzun süre işlevsiz kalması, 90'ı yıllarda bitişiğine inşa edilen betonarme yapının hamama etkisi, 1999 yılında deprem geçirmiş olmasından dolayı hasarlı ve atıl olan hamam yapısının yeniden kullanımı için 2016 yılında restorasyon çalışması başlamıştır. 2018 yılında tamamlanan restorasyon çalışması için rölöve, restitüsyon ve restorasyon projeleri Bozdağ Mimarlık tarafından hazırlanmıştır. Kocaeli Üniversitesi Mimarlık ve Tasarım Fakültesi Mimarlık Bölümü Restorasyon Anabilim Dalından hamamın yapısal davranışının değerlendirilmesi üzerine destek istenmiştir. Yeni Hamam için gerçekleştirilen, yerinde yapılan termal kamera ölçümleri, beton test çekici sonuçları ve SAP2000 simülasyon programı kullanılarak oluşturulan analitik modelden elde edilen analiz sonuçları ile yapısal değerlendirme raporu oluşturulmuştur. Yapının bozulmaları ve nedenleri araştırılmıştır. Bu çalışma, yapının yakın zamanda geçirmiş olduğu restorasyon öncesi durumu ve yapılan sayısal modelde uygulanan yaklaşımları, simülasyon ve analiz sürecini, sonuçları ile belirlenen müdahale kararlarını ve hamamın restorasyon sonrası güncel durumunu anlatmaktadır.

\section{IZMIT YENI HAMAM: TARIHÇE VE MIMARI ÖZELLIKLER}

Tek hamam olarak inşa edilen Yeni Hamam'ın yazılı kaynaklarda yapım yılı ile ilgili farklı tarihleri bulunmaktadır. Galitekin, Kocaeli Su Medeniyeti Tarihçesinden Birkaç Damla kitabında yapının 17. yy. başlarında inşa edildiğini belirtirken Fıratlı 18. yy. ortalarına Öztüre ise yapım yılını 19. yy. olarak belirtmektedir (Galitekin, 2006; Fıratlı 1971; Öztüre, 1983; Kaya, 2009).
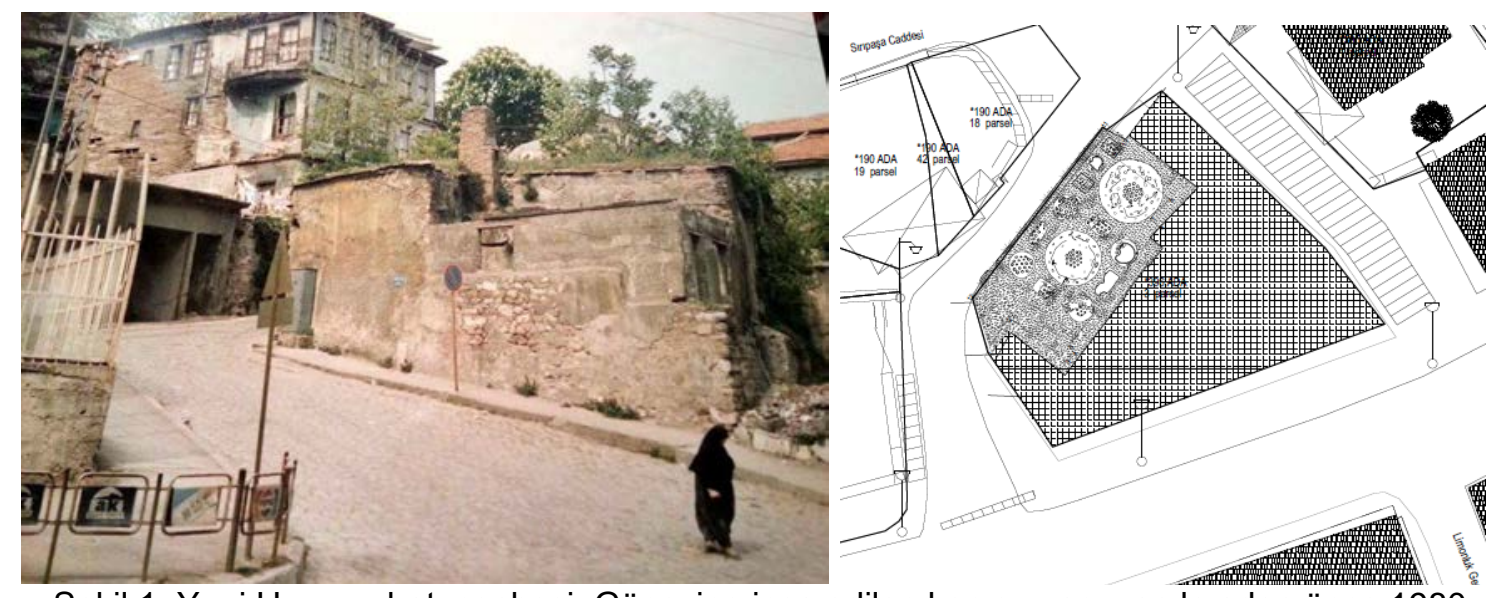

Şekil 1: Yeni Hamam batı cephesi. Güneyine inşa edilen komşu yapı yapılmadan önce 1980 yılları (Kaynak: Erkan Kiraz arşivi, URL- 2) Hamam ve bitişigindeki apartman vaziyet planı

(Bozdağ, 2016b)

Gayrimenkul Eski Eserler ve Anıtlar Yüksek Kurulu 10.11.1979 tarih ve 11612 sayılı kararı ile tescil edilmiştir. İstanbul 2 Nolu Kültür ve Tabiat Varlıkları Kurulu başkanlığının 20.11.1990 tarih ve 2586 sayılı kararı ile onaylı rölöve ve restorasyon projesi ile parselin boş kalan alanına hamamın restorasyonu önkoşulu ile yapı izni verilmiştir (Bozdağ, 2015b). Yapı, kuzeyde Yeni Hamam Sokak, doğuda ve güneyde betonarme komşu yapı ve batıda 50. Yıl İlköğretim Okulu ile çevrilmiştir. Boyutları $20 \mathrm{x}$ 11,2 m olan dikdörtgen şeklindeki hamam sıcaklık, ılıklık ve su deposu/külhan bölümlerinden oluşmaktadır. Yapının bitişiğinde bulunan yapının olduğu yerde camekan bölümünün bulunduğu bilinmektedir. Fıratlı ve Öztüre bu mekânın ahşap olarak inşa edildiğini söylemektedir (Fıratlı 1971; Öztüre, 1983) (Şekil 3). 
Yapının 2016 - 2018 yılları arasında gerçekleşen restorasyonundan önce ılıklık, sıcaklık ve su deposu/külhan mekanlarına dışardan erişim mümkün değildir. Aynı parsel içinde yer alan 7 katlı apartmanın merdiven boşluğundan ılıklık bölümüne zor koşullarda geçilmektedir. Dolayısıyla, ahşap olarak tanımlanan soyunma bölümlerinin komşu bina yapılırken tahrip edildiği sonucu çıkarılabilir (Şekil 1 - 2).

Dikdörtgen biçimli ılıklık mekân, bir büyük kubbe ve kuzeybatı tarafında 2 adet mermer sütun ile taşınan bir küçük kubbe ve iki adet tonoz ile örtülmüş olup bu yapı elemanlarının üzerinde fil gözü delikleri bulunmaktadır. Ilıklık mekânı içerisinde muhdes bir duvar bulunmaktadır. Kubbenin bulunduğu ılıklık ana mekânı ile bu mekânın kuzeyinde bulunan ortada kubbe ve iki yanda tonoz ile örtülmüş diğer mekân arasında $20 \mathrm{~cm}$ kot farkı bulunmaktadır. Sıcaklık mekânına ılıklık mekânından geçilmektedir ve üzeri ana kubbe etrafında yerleşmiş dört adet küçük kubbe ve dört adet tekne tonoz ile örtülmüştür. Ana kubbe, küçük kubbe ve tonozlar diyagonal yerleştirilmiş sekiz adet mermer sütun ile taşınmaktadır. Kuzey cephesinden yapım tekniği anlaşılmaktadır buna göre; yapı malzemeleri olarak yassı tuğla ve moloz taş bulunmaktadır, kubbe ve tonozların kesitleri daha ince olmasından dolayı tuğla ile açıklıklar geçilmiştir (Şekil 3).

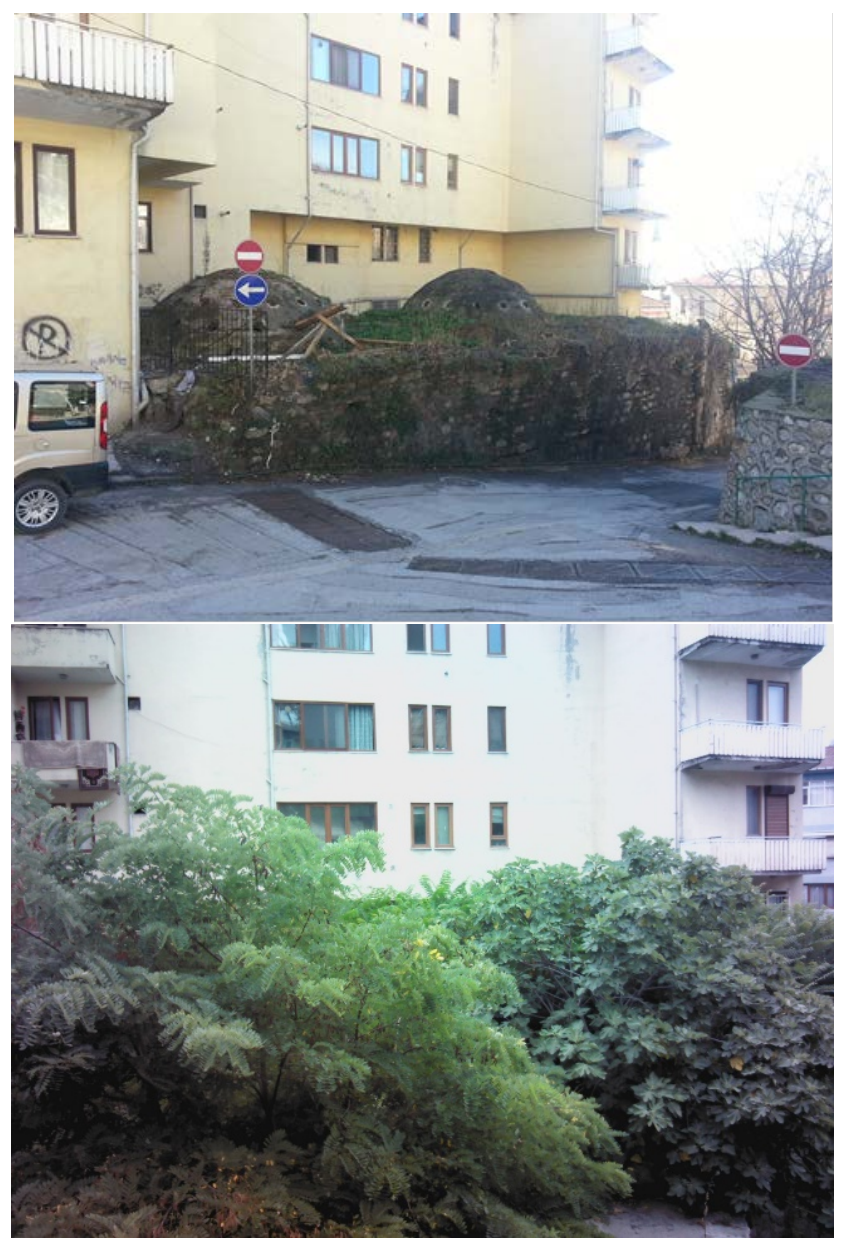

Şekil 2: Yeni Hamam kuzey cephesi. Şubat ve Ağustos 2015 yılı durumu (Kaynak: Emre Kishalı arşivi) 


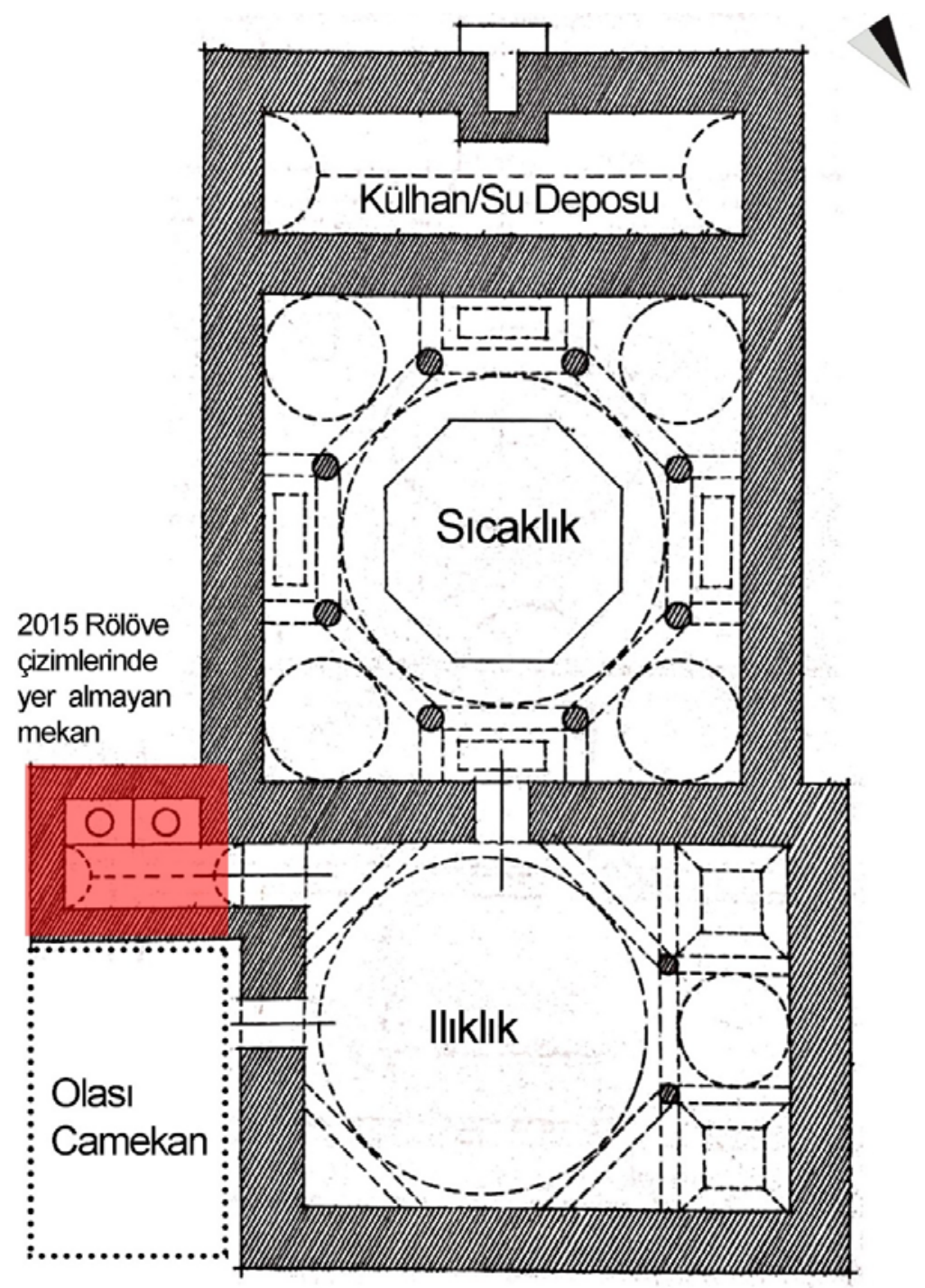

Şekil 3: Yeni Hamam planı. Semra Ünal tezinden yeniden üretilmiştir.1966 (Kaynak: Şennur Kaya)

\section{IZMIT YENI HAMAM: YAPISAL DEĞERLENDIRME}

Söz konusu yapı 4 Şubat 2015, 3 Ağustos 2015 ve 18 Ağustos 2015 tarihlerinde yerinde incelenmiş olup dışarıdan gözlem yolu ve termal kamera görüntüleme yöntemi ile yapısal değerlendirme yapılmıştır. Buna göre yapı elemanları, yapım tekniği ve taşıyıcı elemanlarda yapıdaki hasar, bozulmalar ve müdahale tespit çalışmaları yapılmıştır. Ayrıca yapıya ait taşıyıcı sistem geometrisi ve eleman boyutları daha önce yapı için Bozdağ Mimarlık tarafından gerçekleştirilen rölöve çalışması temel alınarak belirlenmiştir.

\subsection{Yerinde İnceleme ve Hasar Tespiti}

Dışarıdan gözlem yoluyla yapılan ilk incelemelere göre yapısal hasarlar tespit edilmiştir. llıklık mekânının kuzeybatı köşesinde bulunan sütunları birbirine bağlayan gergi demirleri kopmuştur. Mekânı örten ve kuzeyde bulunan küçük kubbe hasar görmüş ve malzeme kayıpları bulunduğundan, ılıklık mekânın dış çevresel etkilere açık olduğu tespit edilmiştir. Sıcaklık mekânında ana kubbeyi taşıyan kemerlerde yapısal çatlaklar gözlemlenmiştir (Şekil 3). Ayrıca, ana kubbede gözlemlenen çatlaklar 
kemerlerdeki kadar derin olmasa da yapısal çatlaklar tespit edilmiştir. Sıcaklık mekânının doğu köşesinde bulunan küçük kubbe ve güneydoğudaki tekne tonoz örtü çökmüştür, mekân çevresel koşullara tamamen açıktır. Ilıklık mekânı kuzeybatı duvarında derin yapısal çatlaklar görülmüştür (Şekil 5). Mermer sütunlar arasında bulunan sivri kemerlerde de yapısal çatlaklar bulunmaktadır. Yapı iki farklı mevsimde ziyaret edilmiş olup çatıda oluşan ağaçların/bitkilerin durumu Şekil 2'de verilmiştir.

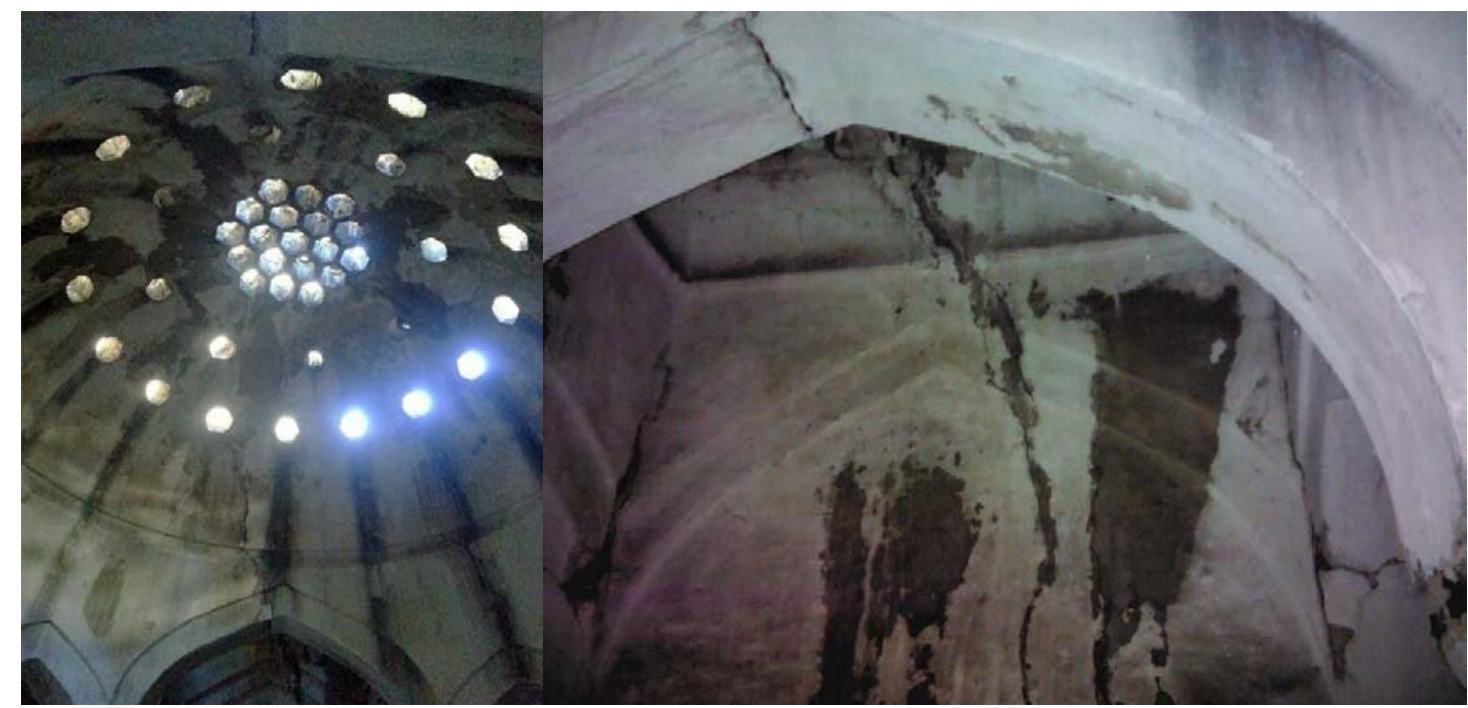

Şekil 4: Sıcaklık mekânı kubbe, kemer ve tonoz yapı elemanlarında gözlemlenen yapısal çatlaklar (Emre Kishalı arşivi, 2015)

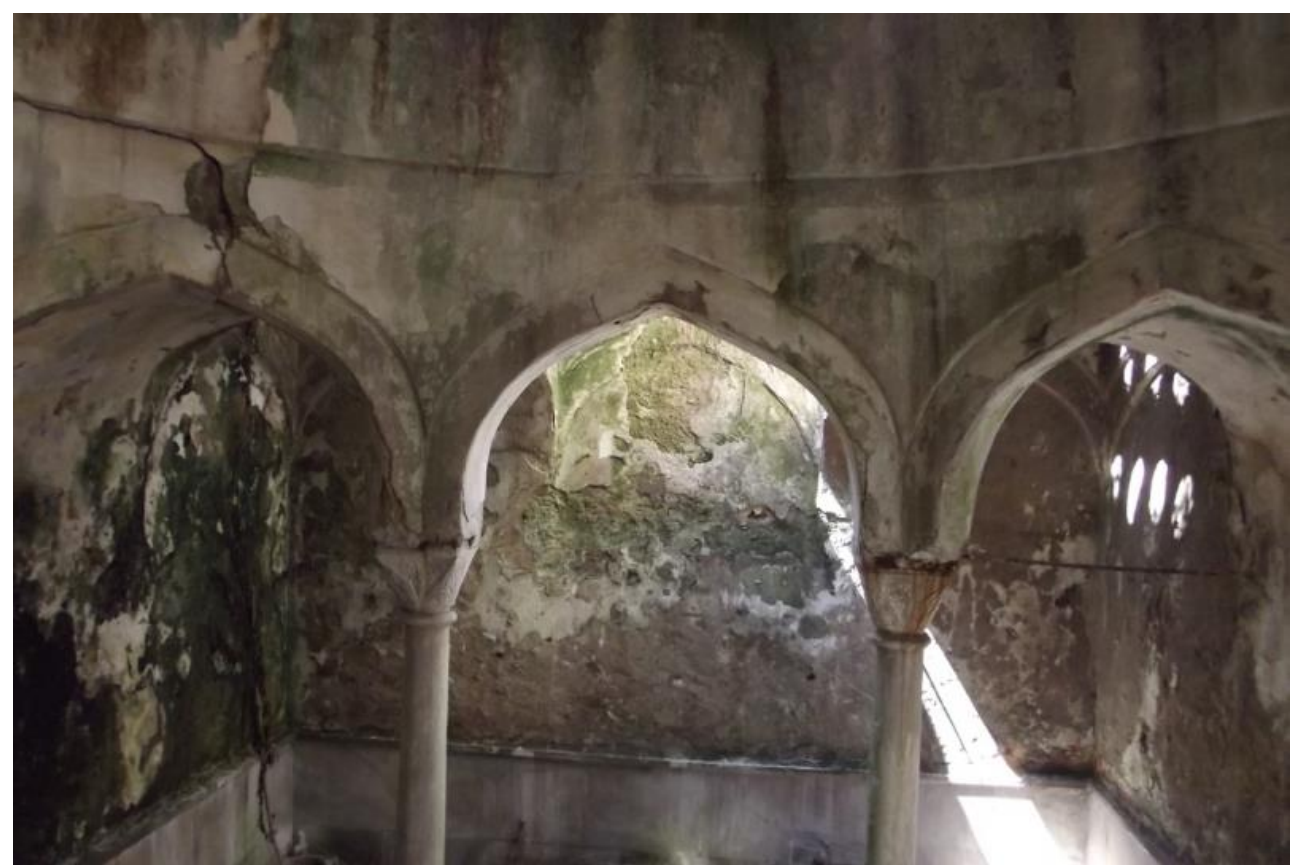

Şekil 5: Ilıklık mekânı kuzeybatı duvarı ve yapısal çatlaklar (Bahadır Bozdağ arşivi, 2015).

\subsection{Termografi ve Sıcaklık - Bağıl Nem ölçümü}

Kızı̈ötesi termografi ile yapı yüzeylerinden ışıma yolu ile yayılan kızılötesi dalgaların dağılımı ve miktarı görüntülenebilmektedir. Duvar, çatı ve yapı elemanlarının yüzeylerindeki sıcaklık dağılımı ve ısı kayıpları farklı malzeme, boşluk, bozulma ve çatlakların bulunduğu kısımlarda farklılaşmaktadır. Buna bağlı olarak, bu yöntem yapı elemanlarındaki alt katmanların belirlenmesinde de kullanılabilir. Örneğin duvar içinde 
yer alan ahşap karkas elemanlar, boşluklar, uyumsuzluklar, ahşap elemanlarda bozulmalar ayrıca, yapı kabuğundaki ısı transferleri ile çatlakları gözlemlemek mümkün olabilmektedir (Jonathan ve Rosina, 2009; Kandemir-Yücel vd. 2007). Ayrıca, iklimsel parametreler olarak sıcaklık ve neme ait verilerin elde edilmesi, yapı kabuğunda gerçekleşen Isı transferi etkilerinin belirlenmesinde büyük önem taşımaktadır. İç ortamda belli bir değer aralıklarında kalan sıcaklık ve bağıl nem değerleri malzeme bozulmalarını etkilediğinden anıtsal ve tarihi yapılar için gereklidir. Küf oluşumu için bağıl nem koşullarının çeşitli kaynaklarda \%70 - 85 arasında olduğunu belirtmiştir (Aktaş vd., 2017).

Bu yöntem, uzun süre işlevsiz kalan Yeni Hamam'da 3 Ağustos 2015 tarihinde 10:00 12:00 saatleri arasında günlük yapı içinde ve dışında yapının mevcut durumunu anlamak için uygulanmıştır. Kızılötesi termografi ölçümler, Flir T640 termal kamerası ve iç mekân ve dış mekân sıcaklık, bağıl nem ölçümleri EXCTECH RHT10 ile yapılmıştır. Dış mekân ölçümü saatlik olarak alınmış olup, iç mekân değerleri ılıklık mekânında dakikalık olarak alınmıştır. Buna göre, Tablo 1'de belirtilen değerler elde edilmiştir. Termal kamera görüntüleri yapıda gerçekleşmiş müdahaleler, yapısal çatlakların derinliği ve zemin kaynaklı su/nem miktarları hakkında bilgiler araştırılmıştır. Ölçümler, ılıklık mekanını örten kubbede önceden kapatılmış özgün fil gözü yerlerinin tespit edilmesini sağlamıştır (Şekil 6). Öte yandan, termografi ölçümleri çatlakların derinliği hakkında nitel veriler sunmuştur, nicel olarak bir çalışma yapılmamıştır. Sıcaklık ve ılıklık mekanlarını örten üst örtüde zaman içinde oluşmuş çatlakların yapısal çatlaklar olduğunu göstermiştir (Şekil 7 - 8).

Tablo 1. 3 Ağustos 2015, 10:00 - 12:00 Yeni Hamam Sıcaklık ve bağıl nem değerleri

\begin{tabular}{|l|l|l|l|}
\hline & Sıcaklık C $\square$ & Bağıl Nem & Çiy Noktası Sıcaklık C \\
\hline Dış Mekân (ortalama) & 35.7 & 42.5 & 20.9 \\
\hline İç Mekân (ortalama) & 26.6 & 75.1 & 21.5 \\
\hline i̇ç Mekân (maksimum) & 30.8 & 89.4 & 22.8 \\
\hline İç Mekân (minimum) & 23.7 & 57.8 & 21.1 \\
\hline
\end{tabular}

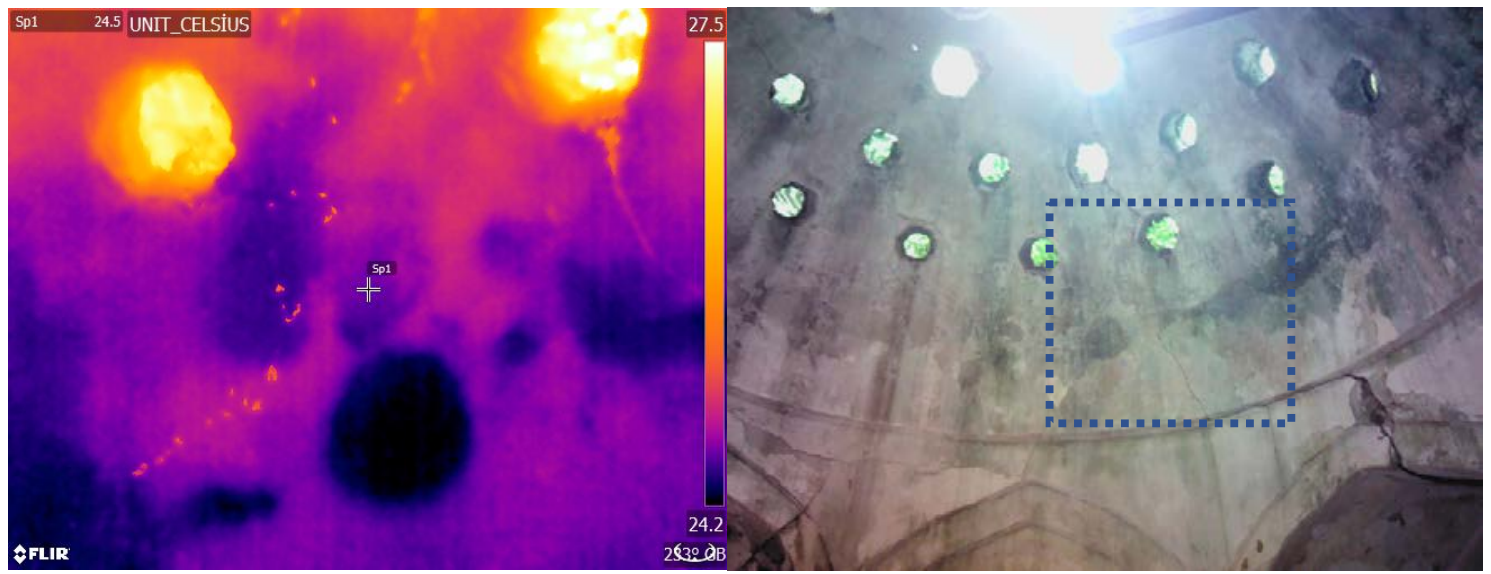

Şekil 6: Ilıklık mekânı kubbesinde farklı malzeme ile kapatılan/sıva uygulaması yapılan fil gözü (Emre Kishalı arşivi, 2015). 


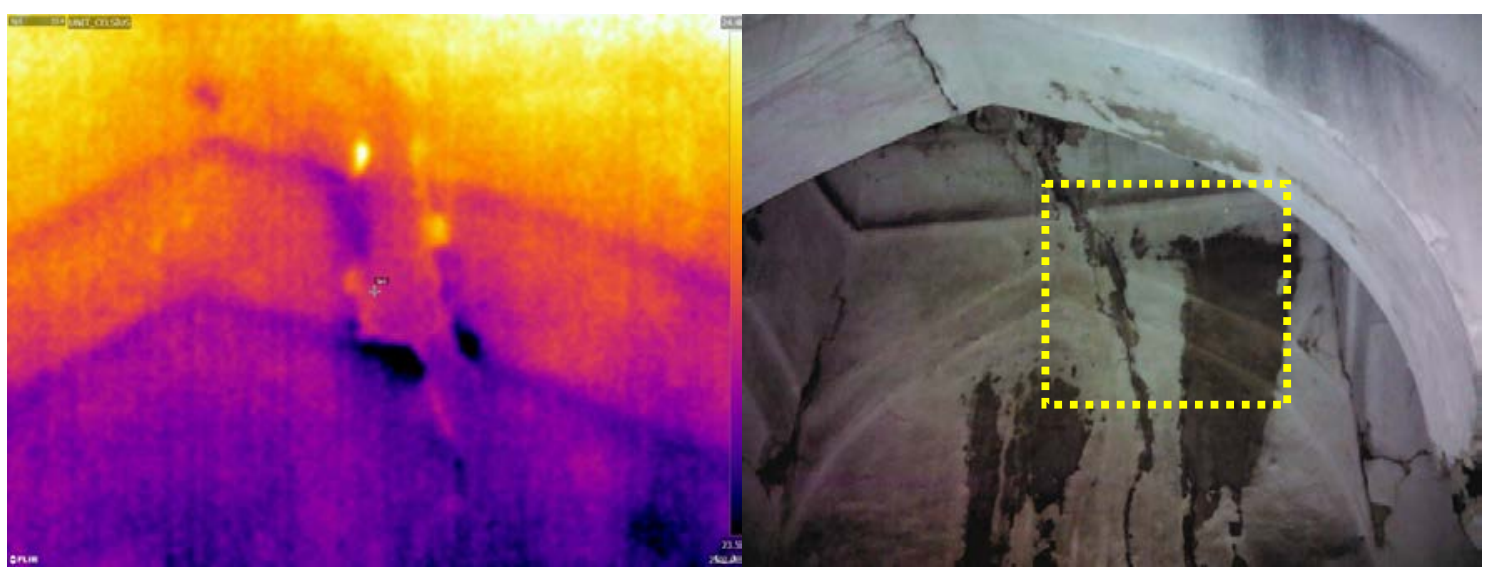

Şekil 7: Sıcaklık mekânı kuzeybatı duvarı yapısal çatlak ve yüzey sıcaklık görseli (Kaynak: Emre Kishalı arşivi, 2015).

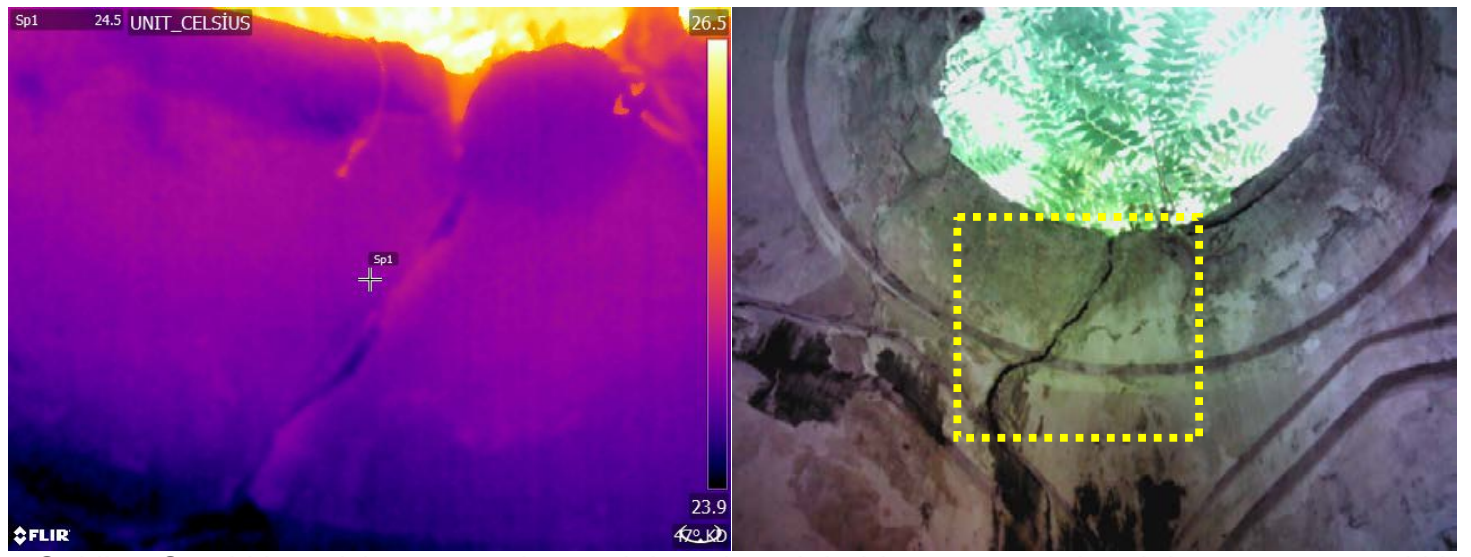

Şekil 8: Sıcaklık mekânı güneydoğu yıkılmış küçük kubbe ve yapısal çatlak ve yüzey sıcaklık görseli (Emre Kishalı arşivi, 2015).

\subsection{Yığma Yapılar Yapısal Analizi}

Tarihi binaların yapısal analizi, taşıyıcı sistem elemanlarının kendi ağırlığı, rüzgâr, deprem, zemin oturmaları ve kullanım sırasında ortaya çıkan çeşitli yük veya fiziksel dış etkiler sonucunda oluşan gerilmeler ve iç kuvvetlerin hesaplanması amacıyla yapılır. Yığma duvarların modellenmesinde hassasiyet düzeyine ve istenen analiz yaklaşımına bağı olarak detaylı mikro modelleme, basitleştirilmiş mikro modelleme ve makro modelleme olarak üç teknik uygulanır. Detaylı mikro modellemede, yığma birimi ve harcın malzeme özellikleri (elastisite modulu, Poisson oranı ve birim hacim ağılıkları) ayrı ayrı değerlendirilir. Bu modelleme tekniği yığma yapı davranışlarının analitik modellemesinde hassas tekniklerinden biridir. Öte yandan tüm yapının tamamının analizinde simülasyon süresi çok uzamaktadır ve özellikle küçük yapılar ya da dikkate alınacak yapının bir bölümünün çözümü için kullanılmaktadır.

Basitleştirilmiş mikro modellemede, yığma birimlerinin boyutları harç tabakasının kalınlığının yarısı kadar genişletilerek harç tabakası inmal edilir. Yığma birimleri birbirinden ara yüzey çizgileri ile ayrılırlar. Sistemde meydana gelecek çatlakların bu ara yüzey çizgilerinde meydana geleceği kabul edilir. Makro modelleme ise, tas, tuğla vb. bloklar ve harç arasında ayrım yapmaksızın, yapı elemanını bir olarak kabul eden ve bu malzemelerin ortak özelliğini yansıtan homojen bir malzeme modelidir. Yığma yapılarda tüm sistemlerin modellenmesi durumunda, özellikle doğrusal olmayan analizlerde mikro modellemede meydana gelen güçlükler sebebiyle yığma birim ve 
harç arasındaki ilişki inmal edilmektedir. Büyük sistemlerin modellenmesi bilgisayar çözüm süresini önemli ölçüde azalttığından tercih edilmektedir.

Vakıflar Genel Müdürlüğü ile İstanbul Valiliği İstanbul Proje Koordinasyon Birimi arasında 2016 yılında imzalanan bir protokol kapsamında Tarihi Yapılar İçin Deprem Risklerinin Yönetimi Kılavuzu (TYIDRYK, 2020) yayınlanmıştır. Sonlu eleman yönteminde, statik ve dinamik yapısal davranışın analizinde, gerilme ve şekil değiştirme arasındaki malzeme bünye denklemi), mesnet (sınır) şartlarını ve gerektiğinde başlangıç şartlarını temsil eden denklemler kullanılır. Sonlu eleman analizinde, tarihi yapıların modellenmesinde bazı kabuller yapılabilir. Mevcut yapı elemanları doğrusal elemanlar, iki boyutlu elemanlar, kabuk elemanlar veya üç boyutlu katı elemanlar kullanılarak yapı modellenebilmektedir (TYIDRYK, 2020).

Analiz yöntemleri 2018 yılında yayınlanan Türkiye Bina Deprem Yönetmeliği'nde (TBDY) belirtilmiştir. Doğrusal tek ve çok modlu statik analizde en yaygın uygulananı doğrusal statik yöntem olup, tek modlu olan Eşdeğer Deprem Yükü Yöntemi ve çok modlu olan Mod Birleştirme Yöntemi olarak adlandırılır. Zaman tanım alanında doğrusal analizinde yapının kütle, sönüm ve rijitlik özelliklerini göz önüne alarak oluşturulan hareket denkleminin, seçilen bir ivme kaydı altında yapı davranışı sayısal çözümlenir. Elastik analiz ile tarihi yapıların elastik hesap yöntemi ile analizinin yapılması ile yapının genel davranışı hakkında fikir sahibi olunur. Bu yöntem ile sonuçların yorumlanması daha kolay ve hata yapma riski azdır (Roca vd.,2010; Toker ve Ünay, 2004). Son olarak ise doğrusal olmayan statik analizde (itme analizi) taşıyıcı sistem elemanları çubuk elemanlarla iki veya üç boyutlu "Eşdeğer Çerçeve" olarak tanımlanır. Doğrusal olmayan artımsal itme analizi ile göçme mekanizması incelemesi yapılabilir (TBDY, 2018; TYIDRYK, 2020). Doğrusal olmayan analiz yönteminde malzeme davranışı ve özelliklerinin iyi bilinmesi gerekmektedir. Literatürde doğrusal olmayan analiz ile incelenmiş tarihi yapı örnekleri ve sonuçları bulunmaktadır. Tarihi yapı ile ilgili verilerin modele aktarılmasıyla gerçeğe yakın sonuçlar elde edilmektedir (Lourenço, 2001).

Bu çalışmada, yapının malzemesi makro modelleme yaklaşımı ile tanımlanmıştır. Mevcut hamam yapısının analizi için modal doğrusal dinamik analizi yapının genel davranışını belirleyebilmek ve hasar görebilirliğini ortaya çıkarmak için seçilmiştir.

\subsection{Yeni Hamam Yapısal Davranış}

Yapı SAP2000 ortamında modellenmiştir. Modelde 1211 kabuk (kalın) ve 11 çubuk eleman kullanılarak yığma duvarlar ve kubbeler bilgisayar ortamına atılmıştır. Duvarlar için $90 \mathrm{~cm}$ kabuk elemanlar kullanılmıştır. Bu modelde üst yapı ile temel arasındaki mesnetler sabit düşünülmüştür. Yapıda bulunan mermer sütunlar çubuk eleman kullanılarak modele aktarılmıştır. Mevcut durumda yapısal çatlaklar ve dilatasyon ile ayrılmış olmasına rağmen komşuluğunda bulunan hamama bitişik betonarme yapı modele aktarılamamıştır. TS 498- Yapı Elemanlarının Boyutlandırılmasında Alınacak Yüklerin Hesap Değerleri kullanılarak (Zatî Kar Yükü Bölgesi II, çatı eğimi \% 0 alınarak) yapıya etkiyen kar yükü $0.75 \mathrm{kN} / \mathrm{m}$ olarak modele tanıtılmıştır (TS 498, 1987). Yapı analizinden elde edilen değerler ile yapıdaki hasarlar karşılaştırılmıştır. Hazırlanan model üzerinde 2 değişik kombinasyon tanımlanmıştır. Bu kombinasyonlar sırasıyla şu şekildedir. 
Kombinasyon 1:

Yükleme 1: Zaman Tanım Analizi X: 1G+1Q+THX

Kombinasyon 2:

Yükleme 2: Zaman Tanım Analizi Y: 1G+1Q+THY

Tanımlanan kombinasyonlarda $Q$ hareketli yük, G ölü yük, THX ve THY 17 Ağustos 1999 tarihinde meydana gelen depremin güney- kuzey doğrultusunda kaydedilmiş $X$ ve $Y$ yönündeki zaman tanım alanında deprem ivme verileridir. Zaman tanım alanı hesap yönteminde kullanmak üzere yer ivme değerleri Afet ve Acil Durum Başkanlığı, Türkiye Ulusal Kuvvetli Yer Hareketi Veri Tabanı adresinden elde edilmiştir (URL - 3). Bununla ilgili veriler Tablo 2'de, grafik ise Şekil 9'da sunulmuştur. Modelde kullanılan malzeme bilgileri Tablo 3.'de sunulmuştur. Elastisite Modülü ve Poisson oranı, yapının öz kütle ve termal genleşme katsayısı literatürde yapılmış daha önceki çalışmalardan alınmıştır.

Tablo 2. Zaman tanım alanı hesap yöntemi için kullanılan veriler.

\begin{tabular}{|l|l|}
\hline Deprem tarihi & $17 / 08 / 1999$ 00:01:39,07 (GMT) \\
\hline Deprem merkez üssü koordinatlar & $40,70000 \mathrm{~N}-29,91000 \mathrm{E}$ \\
\hline Deprem derinliği (km) & 15,9 \\
\hline Deprem şiddeti & $7,4 \mathrm{Md}$ \\
\hline Verilerin alındığı istasyonun koordinatları & $41,05820 \mathrm{~N}-29,00951 \mathrm{E}$ \\
\hline İstasyonun denizden yüksekliği (m) & 130 \\
\hline Kayıt zamanı & $17 / 08 / 199900: 01: 54$ (GMT) \\
\hline Kayıt aralığı (sn) & 0,01 \\
\hline
\end{tabular}

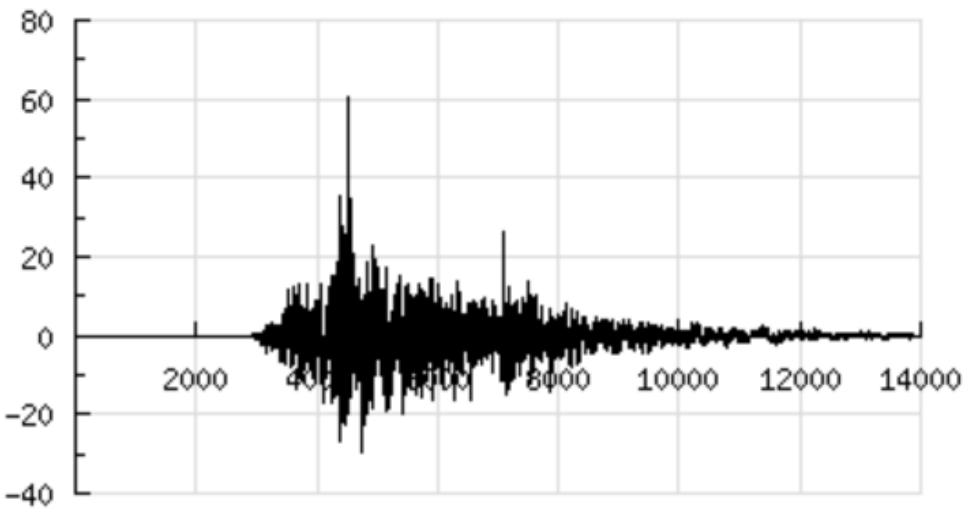

N-S

Şekil 9: Simülasyonda kullanılan zaman tanım alanı grafiği

Tablo 3. Hamam yapısı için dikkate alınan malzeme özellikleri

\begin{tabular}{|l|l|}
\hline Deprem Bölgesi & I. Derece \\
\hline Zemin Grubu & D Grubu \\
\hline Zemin Sınıfı & Z4 \\
\hline Taş Duvar Basınç Dayanımı, fc (MPa) & $10,15-51,80^{3}$ \\
\hline Taş Duvar Elastik Modülü, Ec (MPa) & $450 \mathrm{MPa}$ \\
\hline Tuğla Kubbe Elastik Modülü, Ec (MPa) & $1200 \mathrm{MPa}$ \\
\hline Poisson Oranı & 0.2 \\
\hline Taş Duvar Çekme Dayanımı, fy (MPa) & $2-6$ \\
\hline
\end{tabular}

\footnotetext{
${ }^{3}$ Beton Test Çekiç Deneyi Sonuçları Yapının statik hesabı yapılmadan önce beton çekiç testi yapının 9 farklı noktasına
} uygulanmıştır. Test sonuçlarına göre ortalama duvar basınç dayanımı 10,15 - 51,80 MPa arasında bulunmuştur. 
Yapının modal davranışına bakılarak rijitlik dağılımı ve burulma düzensizliği olup olmadığı hakkında fikir sahibi olunabilmektedir. Yapıların titreşim periyotlarını hesaplayarak ve mod şekil değiştirmelerine bakılarak yapısal değerlendirme yapılabilir. Yapının rijitliği ve kütlesine bağlı olan yapı periyot değerleri ile zemin hâkim periyotunun bilinmesi analiz için gereklidir. Söz konusu iki periyot değerinin aynı olması durumunda zemin titreşimleri, bina titreşimini artırmaktadır. Bu duruma rezonans adı verilmektedir.

Hamam yapısının ilk 6 modal davranışı Tablo 4'te sunulmuştur. İlk üç hâkim titreşim sırasıyla betonarme plak döşemede, $Y$ yönünde beden duvarlarında ve $X$ yönündeki beden duvarlarında görülmüştür. Zemin parametrelerinden gelen hâkim periyot değeri 0,37 olarak belirlenmiştir. Hesaplardan elde edilen periyot değerleri ise bu değerlerin altındadır ve aynı olmadığı için rezonans riskinin bulunmadığı görülmüştür.

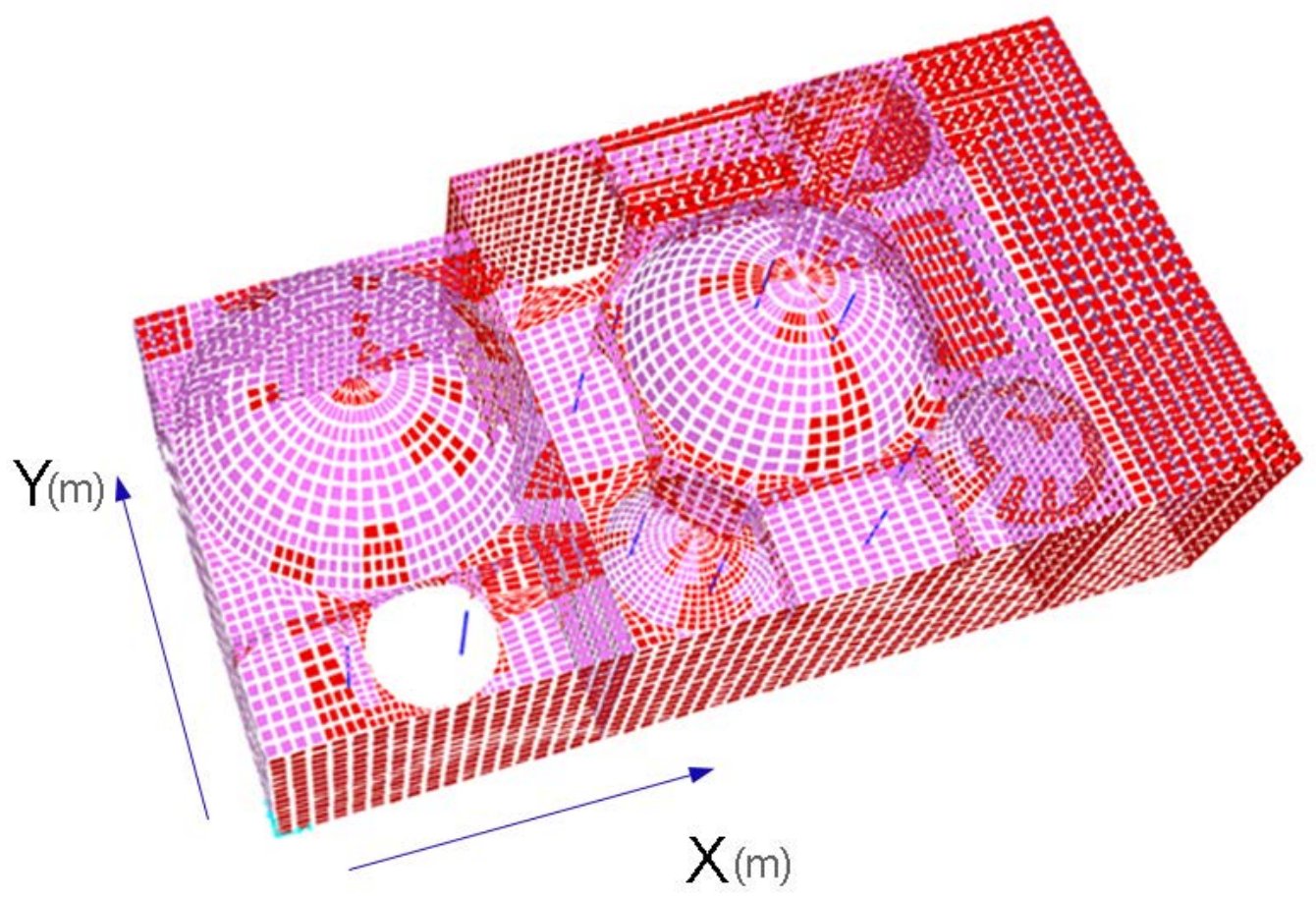

Şekil 10: Yeni Hamam yapısı SAP2000 modeli genel görünüş. 
Tablo 4. İlk altı moda ait değerler ve modal şekil değiştirmeler

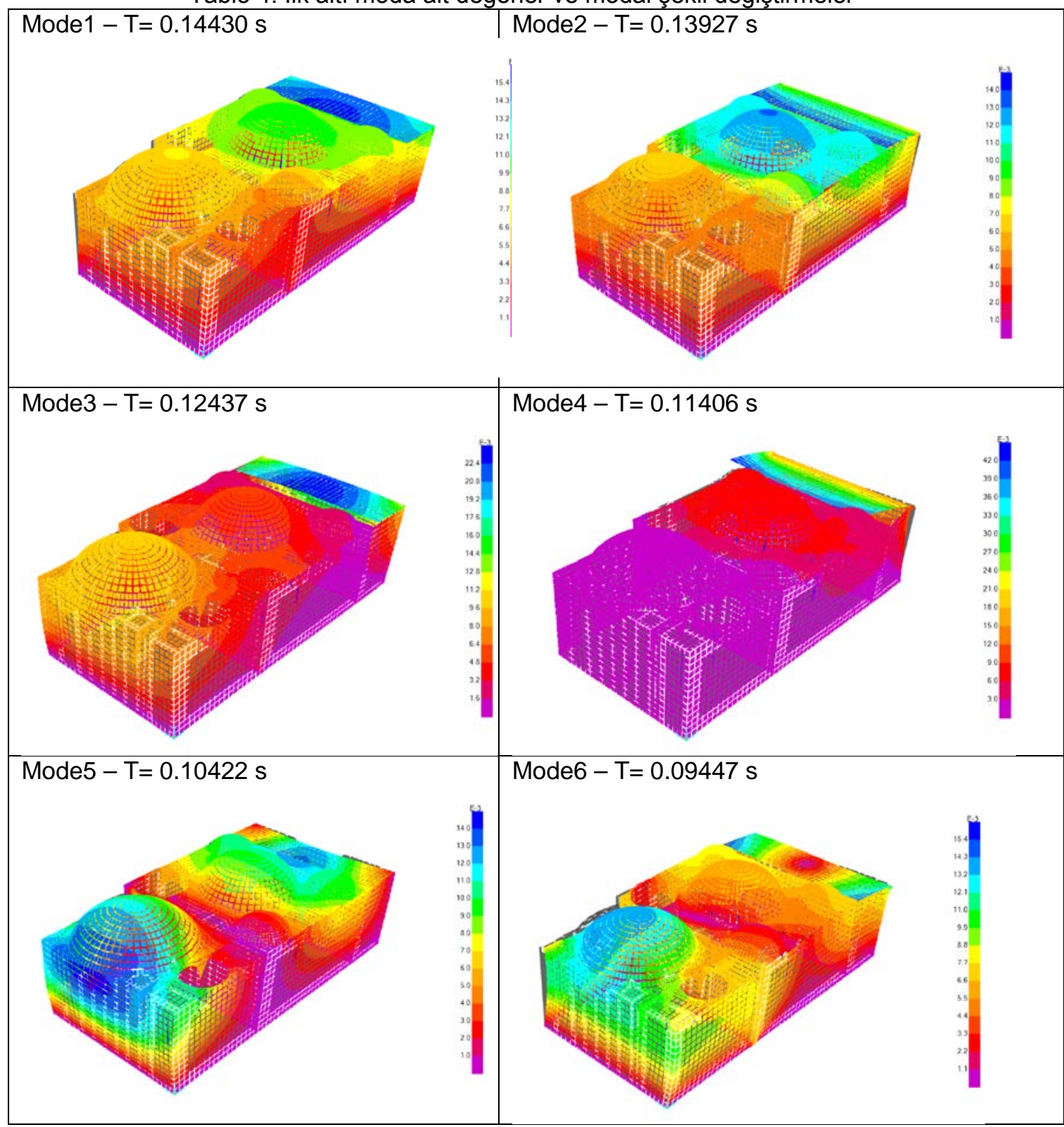

Kombinasyon 1'e göre 17 Ağustos 1999 depremi kaydedilmiş yer ivme değerleri göz önünde bulundurularak modeldeki maksimum yer değiştirme ve gerilmeler hesaplanmıştır. Buna göre meydana gelen maksimum $X$ ve $Z$ yönünde yer değiştirme külhan/su deposu ile sıcaklık mekânı birbirinden ayıran duvarın üst örtü ile birleştiği noktada meydana gelmiştir.

$X$ ve $Y$ yönünde elde edilen gerilme dağılımları Şekil 11'de verilmiştir. Analiz neticesinde, ılıklık mekânın kuzeyinde bulunan alanın üst örtüsünde çöken kubbenin etrafında ve sıcaklık mekânında çöken kubbeyi taşıyan kemerde kabul edilen basınç ve çekme dayanımından yüksek değerler bulunmuştur. $Y$ yönünde elde edilen gerilme sonuçları incelendiğinde sınır değerleri aşan bölgelerin ılıklık ve sıcaklık bölümleri arasındaki duvarın üst örtü birleşim noktasında ve sıcaklık mekanının bitişiğine inşa edilmiş betonarme yapıyla olan komşu duvarda olduğu görülmüştür. 


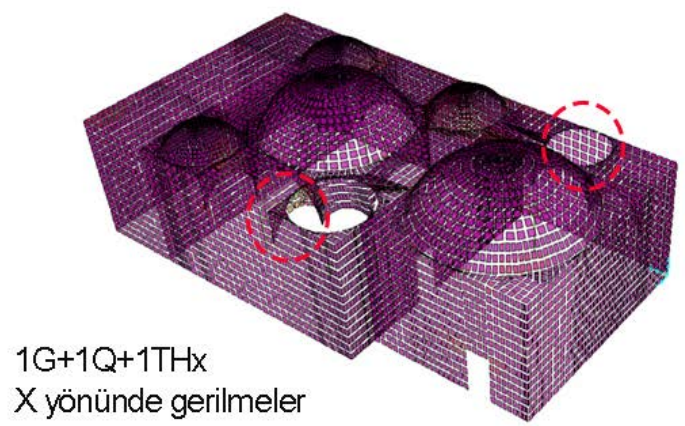

Şekil 11: Yeni Hamam SAP2000 modeli Kombinasyon 1 analiz sonuçları.

Öte yandan $Y$ doğrultusunda etki eden deprem kuvvetlerini içeren Kombinasyon 2'ye göre 17 Ağustos 1999 depremi için kaydedilmiş yer ivme değerleri göz önünde bulundurularak analiz sonuçları incelenmiştir. Kombinasyon 1'de elde edilen maksimum değer bu kombinasyon sonuçlarında da külhan/su deposu ile sıcaklık mekânı birbirinden ayıran duvarın üst örtü ile birleştiği noktada meydana gelmiştir.

$X$ yönünde gerilme analizi incelendiğinde, sıcaklık mekânında ana kubbenin ılıklık mekanına yakın ana kubbeyi taşıyan kemerde ve ana kubbenin kuzey ve güneyinde bulunan küçük kubbeleri taşıyan kemerlerde kabul edilen basınç ve çekme dayanımından yüksek değerler bulunmuştur. $Y$ yönünde elde edilen gerilme sonuçları incelendiğinde sınır değerleri aşan bölgelerin sıcaklık mekânında ana kubbe ve kuzeybatı küçük kubbe arasında bulunan alanda olduğu görülmüştür (Şekil 12).
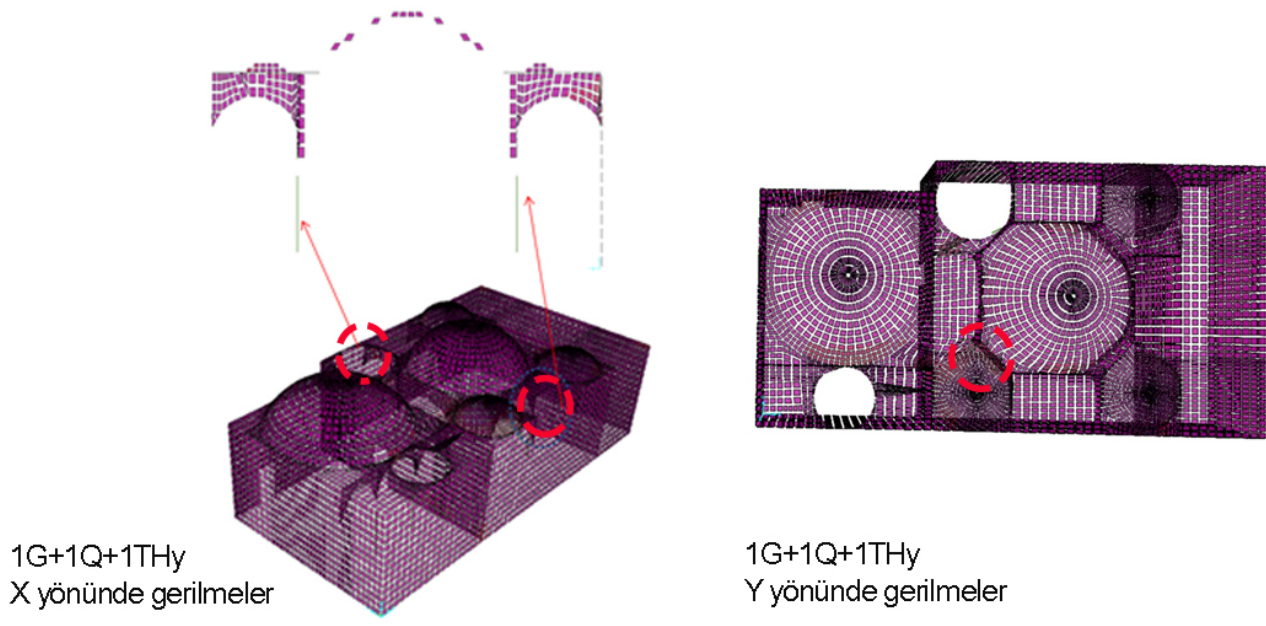

$1 \mathrm{G}+1 \mathrm{Q}+1 \mathrm{THy}$

$Y$ yönünde gerilmeler

Şekil 12: Yeni Hamam SAP2000 modeli Kombinasyon 2 analiz sonuçları.

\subsection{Müdahaleler için Öneriler}

Yapının genel olarak model analiz sonucu değerlendirildiğinde $X$ ve $Y$ yönünde etki eden kuvvetler altında, yapının mevcut hasarlı olan bölgelerinde elde edilen sonuçların kabul edilen basınç, çekme ve kesme dayanımına yaklaştığı ve geçtiği gözükmektedir. Yeni Hamam göz önünde bulundurulduğunda zemin (komşu parsel) ya da yatay kuvvetlerin oluşturduğu gerilmelerin malzeme kesme dayanımından fazla olduğu ve derin çatlakların oluştuğu görülmektedir. Sıcaklık ve ılıklık mekânlarında görülen büyük yapısal çatlaklar için elde edilen bulgulardan sonra aşağıdaki mekanizmaların yapıda meydana gelen hasarlara neden olduğu düşünülmektedir. Şekil 13'te sunulan görsel ile diyagonal çatlak nedenleri irdelenmiştir. 
Bozdağ Mimarlık'ın kuzeydoğu cephesindeki kapsamlı rölöve çalışmalarından duvarın düşeyden sapma değerinin az olduğu bulunmuştur. Lazer tarayıcı ile taranan tarihi yapının iç yüzeyinde $1-2 \mathrm{~cm}$ yüzey bozuklukları bulunmaktadır. Yapısal olarak müdahale görmesi gereken yapı elemanlarının sıcaklık mekânında güneybatı ve kuzeydoğu duvarları olduğu sonucu çıkarılmıştır. Yapının güneyine eklenmiş olan ve hamamdan kütlece çok ağır olan 7 katlı betonarme yapı nedeniyle yapının güneydoğu duvarında yatay bir yük oluşmuş ve bu cephe duvarının yapıdan uzaklaşması nedeniyle bu çatlakların oluştuğu gözlenmiştir. Sıcaklık mekânında kubbede görülen büyük çatlağın komşu parseldeki zemin/temel müdahalelerinden kaynaklı, yapı elemanında meydana gelen kesme/çekme kuvvetlerinden kaynaklandığı, Ilıklık mekânında yine aynı nedenden dolayı kubbe ve kemerlerin ayrıldığı düşünülmektedir (Şekil 13- 14).

Özetle yapının restorasyon öncesi yapısal olarak hasarları komşuluğundaki yapı, malzeme kayıpları, çevresel faktörler ve gergi elemanlarının tahribatı diye sıralanabilir. Yedi katlı betonarme yapının inşası sırasında ve sonrasında olan baskısı hamam üzerinde olumsuz etkiler bırakmıştır. Ana kubbedeki fil gözlerinin ortadan kalkması, yapısal çatlakların bulunması ve küçük kubbelerin çökmesinden dolayı yapı yağmur, rüzgâr, kar gibi dış etkilere açık kalmıştır. Yapının üst örtüsünde büyük ağaçlar oluşmuştur (Şekil 14).

Son olarak çekme kuvvetlerine karşı çalışan kubbe altında izleri görülen gergi demirlerinin kaybolması yapının hasar görebilirliğini artırmaktadır. Yapının genel yapısal davranışının modellendiği SAP2000 programında gerçekleşen sonlu elemanlar analizinde elde edilen kritik alanların, yapının mevcut durumunda da yapısal çatlaklara sahip olduğu belirlenmiştir. Analize ek olarak ılıklık ve sıcaklıkta görülen kubbe ve tonoz çatlakları ve kubbeyi taşıyan kemerlerde de yapısal bozulmalar görülmüştür bunun nedeni ise üst örtüde ağaçların yaptığı olmuşuz etkilerdir.

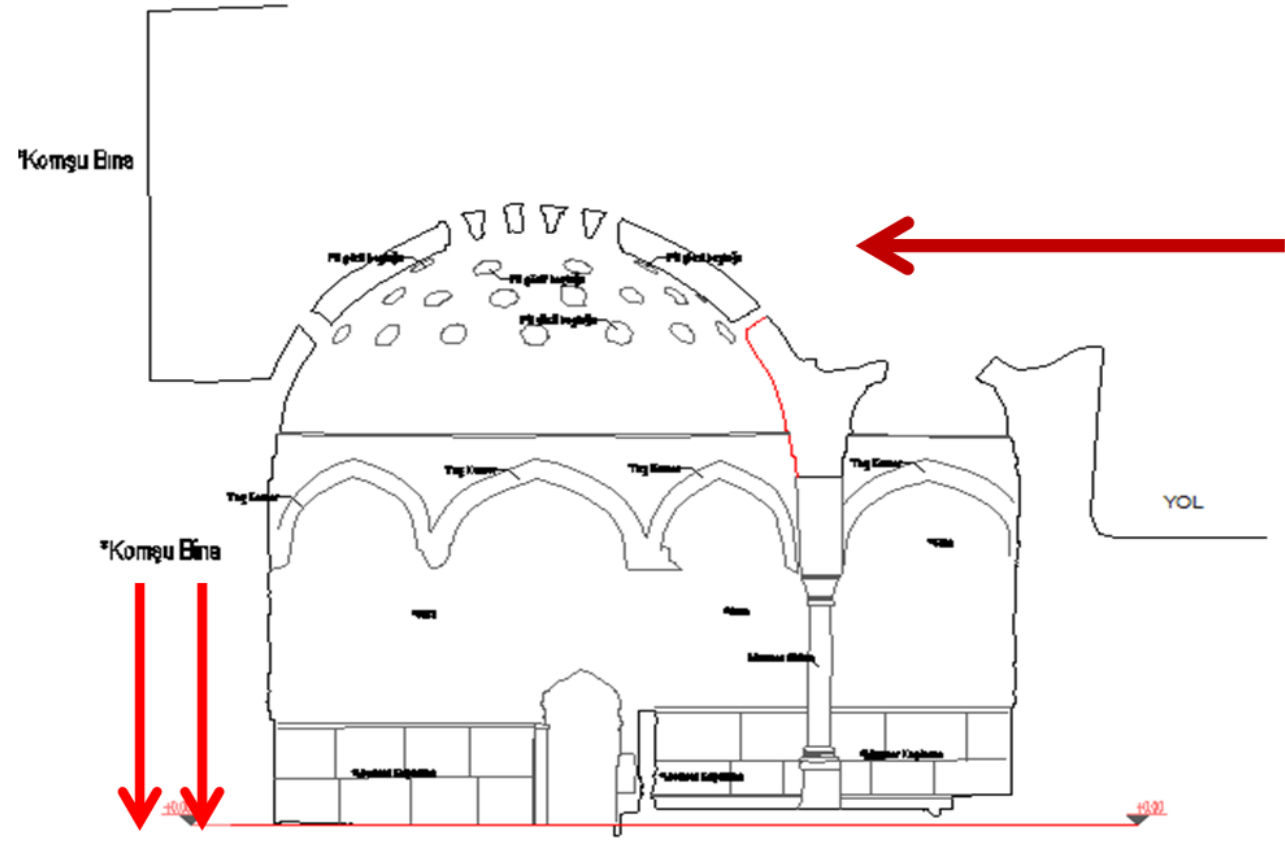

Şekil 13: Yeni Hamam'da görülen yapısal çatlakların nedeni. (Bahadır Bozdağ çiziminden yeniden üretilmiştir. 


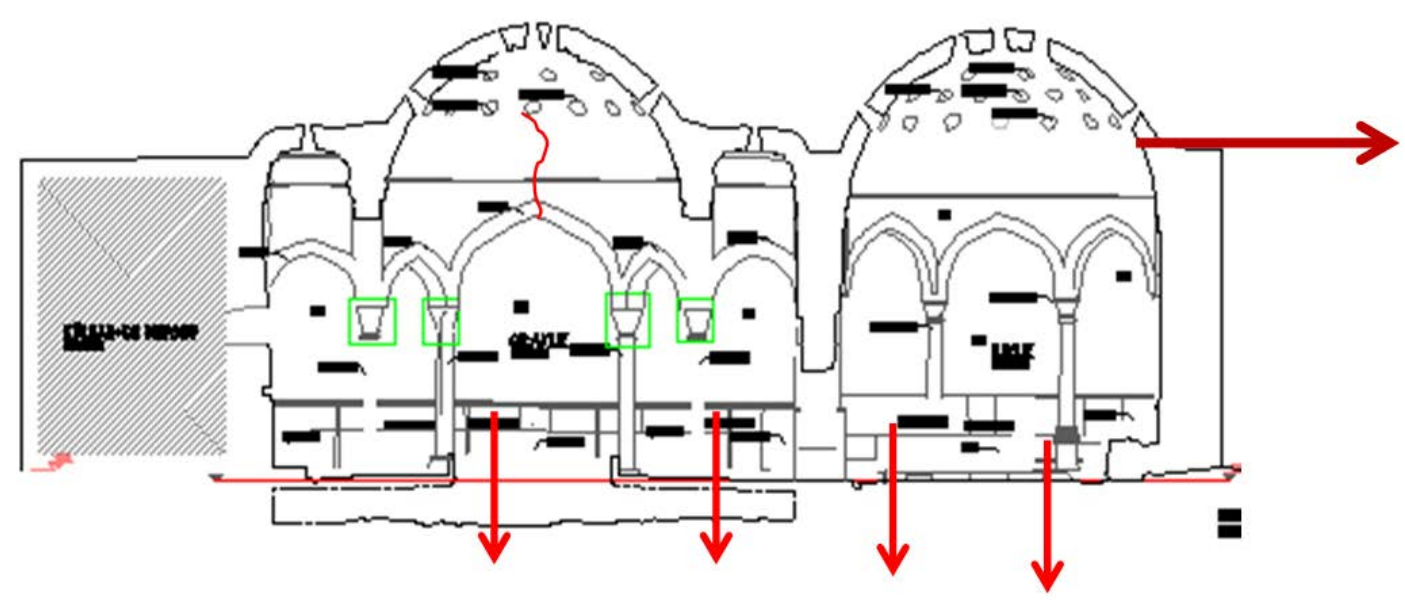

Şekil 14: Yeni Hamam'da görülen yapısal çatlakların nedeni. (Bahadır Bozdağ çiziminden yeniden üretilmiştir.

Termal kamera ve sıcaklık/bağıl nem ölçümleri yapı içinden farklı bulgulara ulaşmayı sağlamıştır. Dışardaki çevresel koşullara kıyasla yapıda Sıcaklık değerleri daha az olmakla birlikte bağı nem ortalamasının \%75'lerde olduğu hatta \%90'lara çıktığı gözlenmiştir. Bu yapı içinde su/nem miktarının fazlalığına işaret etmektedir ve çevresel koşulların yapı ve malzeme için zararlı etkileri için acil önlem alınması gerekliliğini doğurmuştur.

SAP2000 programı ile 17 Ağustos 1999 deprem verileri kullanılarak yapılan çözümlemeler, termal kamera ve sıcaklık/bağıl nem ölçümleri ile geliştirilmiştir. Buna göre Yeni Hamam yapısı için aşağıdaki durumlar önerilmiştir. Yapının üst kotunda bulunan bitki ve ağaçların acil olarak kaldırılması, yapının çevresel koşullardan korumak için önlem alınması, nem kaynaklı problemlere neden olan zemin suyu seviyesi (drenajı)/kubbe örtü hasarlarının tamiri önerilmektedir. Yapısal olarak çatıda derin çatlaklar bulunmaktadır, bu çatlakların bulunduğu bölgede bozulmuş malzemelerin, yapı askıya alınarak özgün malzeme ile değiştirilmesi gerekmektedir. Böylece yapının bütünlüğü sağlanmış olacaktır.

\section{IZMIT YENI HAMAM: RESTORASYON}

İzmit Belediyesine ait yapının restorasyon çalışmaları 2016 yılında başlamıştır. Bozdağ Mimarlık tarafından hazırlanan rölöve, restitüsyon ve restorasyon projeleri Kocaeli Kültür Varlıklarını Koruma Kurulu tarafından onaylandıktan sonra ARC Mimarlık Mühendislik yüklenici firması tarafından restorasyon uygulaması gerçeklemiştir. Sergi salonu olarak projelendirilen yapının restorasyon sonrası kullanımı Kocaeli Dokümantasyon Merkezi'ne aittir.

Yapıya uygulanan müdahaleler arasında beden duvarlarına iç ve dış sıva raspası yapılarak ilave çatlak kontrolü yapılmıştır. Yapısal olarak tespit edilen çatlaklara enjeksiyon karışım tamir harcı uygulanmıştır. Harç puzolanik katkılı hidrolik kireç harcı enjeksiyon ile uygulanmıştır. Kubbelerin altında yer alan fakat çürüyen gergi demirleri yenilenmiştir. Bu işlem için yapının üst örtüsü askıya alınmıştır (Şekil 16- 17) (Bozdağ, 2015a). 


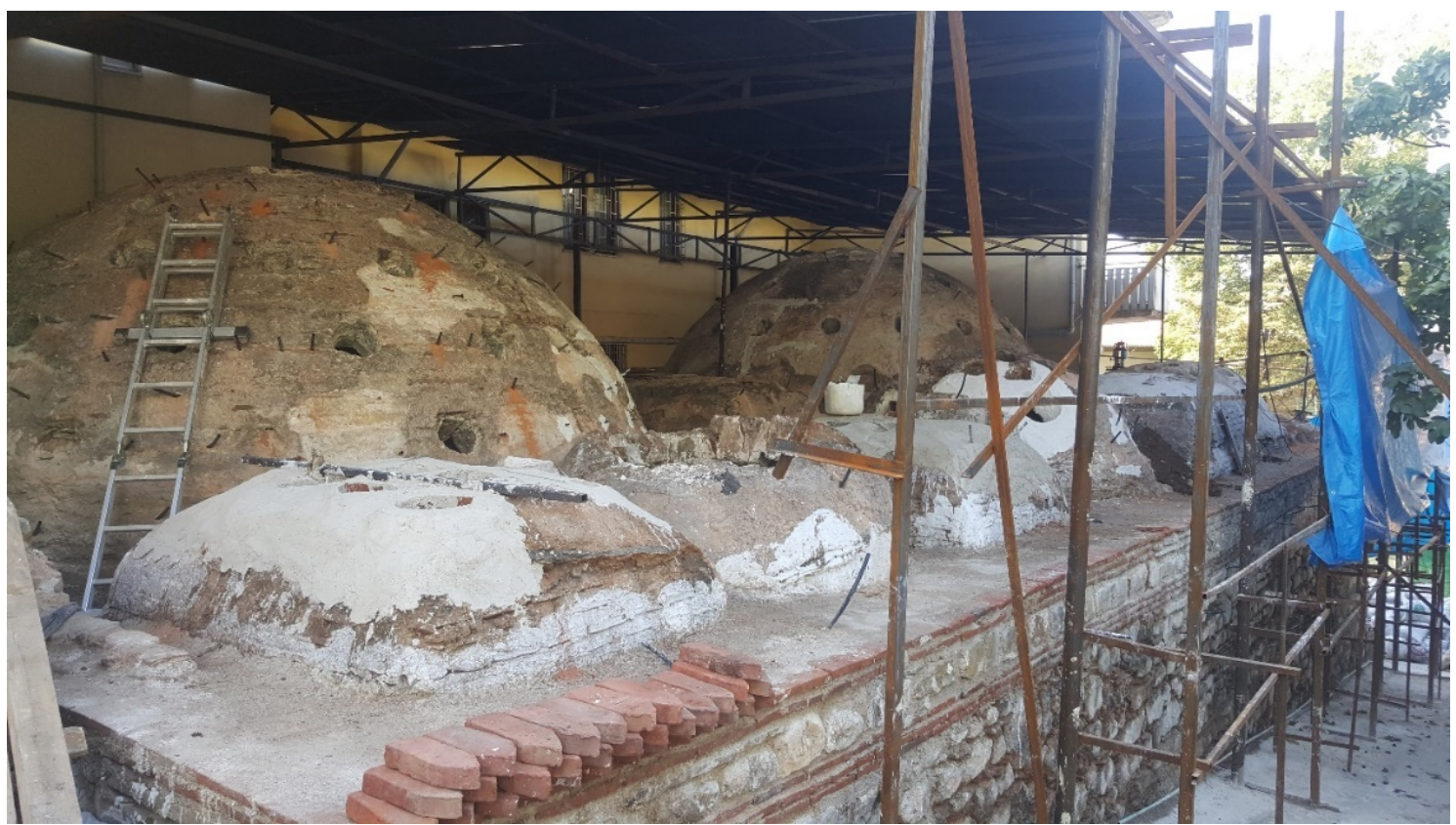

Şekil 15: Hamam hidrolik kireç harcı kubbe enjeksiyon ve kirpi saçak yapımı (Kaynak: Emre Kishalı arşivi, 2016).

Restorasyon sırasında yapıya uygulanan müdahalelerden biri de Yeni Hamam'ın dış duvarlarında ve çatısında bulunan bitkilerin ve ağaçların kaldırılmasıdır. Bitki ve ağaç köklerin kaldırılması için öncelikle mekanik temizlik ve gerekli olan durumlarda kimyasal temizleme yapılmıştır. Bu işlemden sonra çökmüş olan küçük kubbe ve tonozlar özgün tuğla ile örüldükten sonra toprak sıva üzerine kurşun kaplama yapılmıştır ve eksik olan fil gözleri yerleştirilmiştir. Hamam beden duvarlarında meydana gelen malzeme kayıplarında duvar alanları taş-tuğla malzeme ile tamamlanmıştır (Şekil 16). Kirpi saçak yeniden yapılmıştır ve uygun horasan harç (kireç, kireç taşı, tuğla kırığı, tozu ve elek altı dere kumu) ile taş tuğa duvar derzleri tamamlanmıştır (Şekil 15). Yapının iç yüzeyi ise kireç esaslı sıva harcı üzerine kireç badana ile kaplanmıştır. (Bozdağ, 2015a). Yapıya yapılan müdahale ise betonarme apartmanın inşasından sonra hamamın güneybatısında bulunan üçgen alanı kaldırılarak külhan/su deposu mekânı içinden sergi salonuna giriş için boşluk açılmıştır. Öte yandan bu alandan sıcaklık mekanına da geçiş için kapı boşluğu açılmıştır.
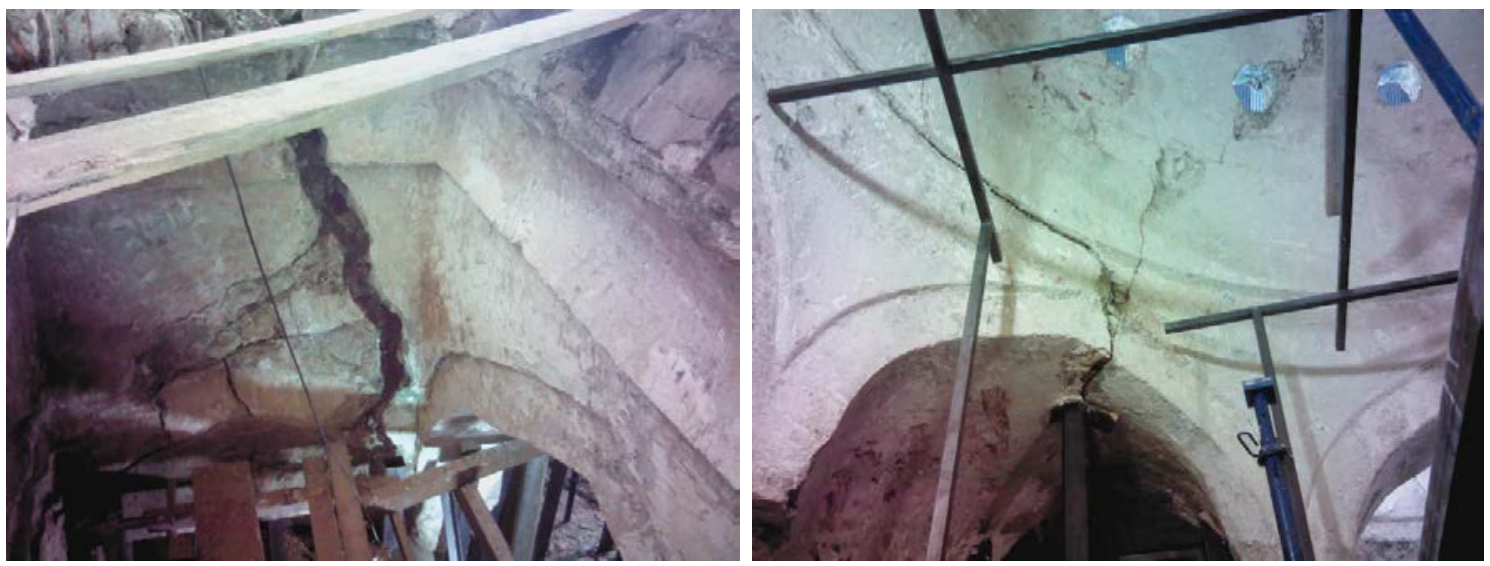

Şekil 16: Hamam bitkilenme mekanik ve kimyasal müdahalelerden sonra çatlak görünümü (sol), sıcaklık ana kubbeyi taşıyan kemerlerde görülen çatlaklar yapının askıya alınması (sağ).

(Kaynak: Emre Kishalı arşivi, 2016). 


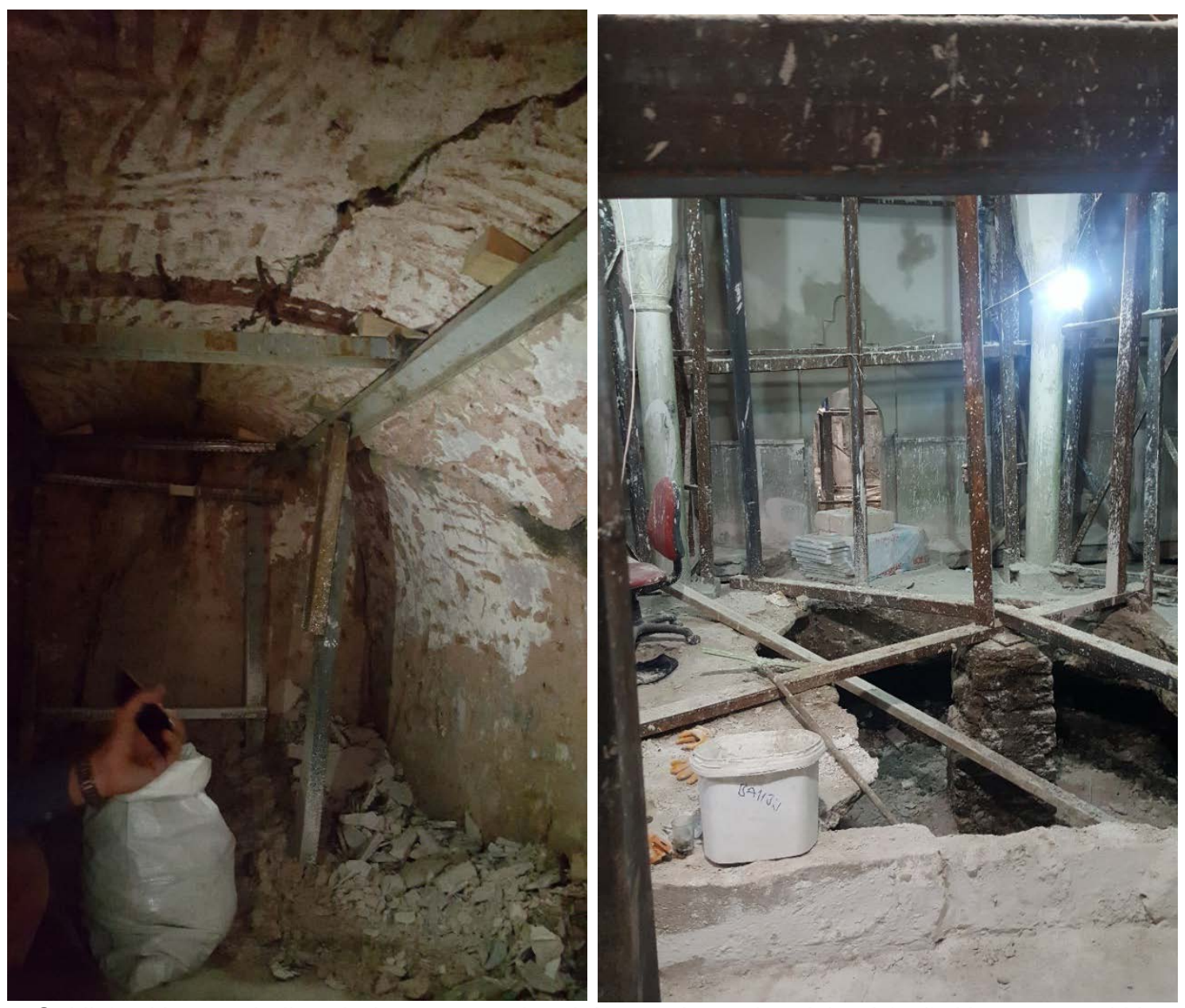

Şekil 17: Hamam külhan bölümü yapısal çatlak ve askıya alma işlemi (sol). Hamam sıcaklık bölümü döşeme müdahalesi (sağ). (Kaynak: Emre Kishalı arşivi, 2017).

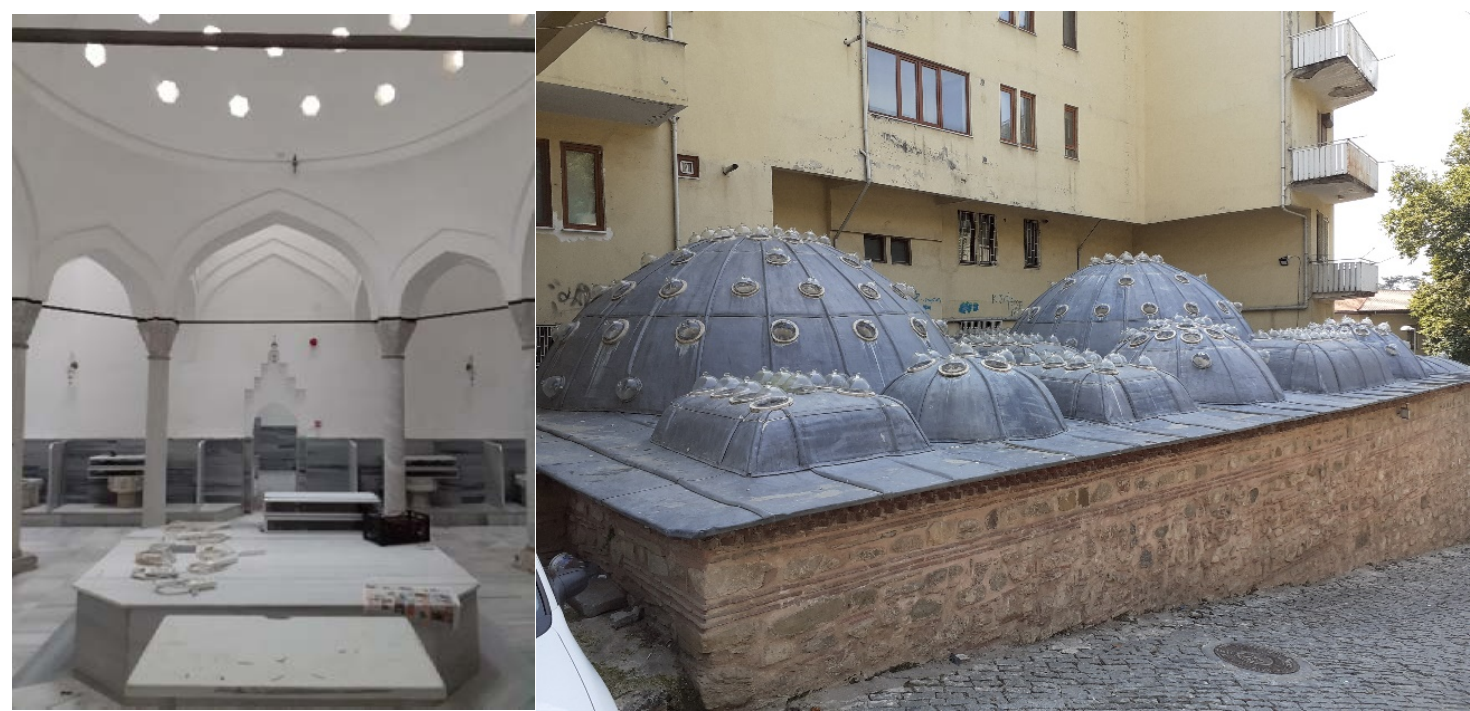

Şekil 18: Restorasyon sonrası sıcaklık bölümü. (Kaynak: Emre Kishalı arşivi, 2017). 


\section{DEĞERLENDIRME VE SONUÇ}

Tarihi yapıların, yapısal analizin için en önemli yaklaşım bütüncül yaklaşımdır. Yapının geçirdiği tarihsel süreç, yapılan müdahaleler, malzeme, mimari ve yapısal özellikler bir bütün halinde irdelenmelidir. Tarihi yapıların yapısal ve termal davranışlarını anlayabilmek ve sağlıklı kararlar verebilmek için uzun ve sürekli çalışmalar yapılmalıdır. Malzeme ve yerinde yapılması gereken ölçümler, yapısal çatlakların gözlemlenmesi gerekmektedir. Tarihi miras için üniversite (akademik çalışma, yüksek lisans - doktora öğrenci çalışmaları) - belediye - vakıflar- özel teşebbüs iş birliği; kapsamlı araştırma ve diğer disiplinler ile sürekli çalışma yapılması ve bu çalışmaların erişimi kolay bir biçimde yayınlanması gerekliliği önemlidir.

Yeni Hamam bir dilatasyon ile ayrılmış da olsa, aynı parselde sonradan yapılmış betonarme yapı, tarafından baskı altına alınmıştır. Aynı parselde bulunan bu yapının herhangi olası bir depremde göstereceği davranış ile tarihi yapının değerini bozma ihtimali vardır. Öte yandan kuzeyde bulunan ve trafiğe açık olan yol ve çalışmaları da yapıyı olumsuz etkilemiştir. Çevresel koşullara maruz kalan yapı için, hasar görmüş kubbe ve yapı üstünde bulunan ağaçlar için acil önlem alınması gerekmektedir. Yapıda gözlemlenen hasarlar nedenlerinin önceki depremler, niteliksiz imar faaliyetleri, çevresel koşullar ve koruma sorunsalı olarak sıralanabilir.

Tarihi yapılardaki malzeme, yapısal eleman bağlantıları ve zemin zaman içerisinde değiştiğinden, dijital ortamdaki hiçbir model yüzde yüz olarak gerçeği yansıtmayacaktır. Bu raporda SAP2000 programı için yapı malzemesi verileri literatürden alınmıştır. Yeni Hamamın yapısal genel davranışı incelenmiş olup, elde edilen veriler alanda yapılan basınç dayanımı ile karşılaştırılmıştır. Araziden elde edilen basınç dayanımı değerler, TBDY'e göre yapılan çözümler ve 17 Ağustos 1999 deprem verileri kullanılarak yapılan analizler yüzde yüz gerçek verileri veremez. Genel olarak yapının davranışını açıklamak mümkündür. Hesaplanan basınç ve kayma gerilmelerinin alanda yapılan basınç değerleri ile karşılaştırılması durumunda, kritik alanların az olduğu görülmektedir. Basınç ve kayma gerilmeleri açısından kritik alanların hasar görmüş/yıkılmış kubbe, kubbe birleşim yerleri, tonoz ve duvar birleşim yerleri olduğu gözükmektedir. Doğrusal olarak yapılan analizde, kubbe ve kemerlerde yük birikmelerinin fazla olduğu görülmüştür, fakat çekiç ile yapılan ortalama basınç dayanım değerlerinin altında kalmışlardır. Yapının detaylı analizleri doğrusal olmayan dinamik analizler ile ilave olarak çalışılabilir. Özellikle 7 katı betonarme yapının, tarihi hamam yapısına olan etkisi üzerine, özellikle çarpışma tehlikesine karşı gelecekte çalışmalar yapılmalıdır. 


\section{KAYNAKLAR}

Aktaş, Yasemin Didem, D’Ayala, Dina, Blades, Nigel, Calnan, Christopher, An Assessment Of Moisture Induced Damage In Blickling Hall In Norfolk, England, Via Environmental monitoring, Heritage Science, 2017, 5 (5), 1-10.

Bozdağ, Bahadır, Yeni Hamam Rölöve Raporu, İzmit, Kocaeli, 2015b

Bozdağ, Bahadır, Yeni Hamam Restorasyon Raporu, İzmit, Kocaeli, 2015a

Fıratlı, Nezih, Izmit Şehri ve Eski Eserleri Rehberi, İstanbul, 1971.

Galitekin, Ahmet Nezih, Kocaeli Su Medeniyeti Tarihçesinden Birkaç Damla, Kocaeli, 2006.

ICOMOS Turkey, Convention for the Conservation Architectural Heritage http://www.icomos.org.tr/Dosyalar/ICOMOSTR_0623153001387886624.pdf (Erişim Tarihi: 18.05.2020)

Kandemir-Yücel, Ayşenur, Tavukçuoğlu, Ayşe, Caner-Saltık, Emine Nevin. In situ assessment of structural timber elements of a historic building by infrared thermography and ultrasonic velocity, Infrared Physics \& Technology, 2007, 49 (3): 243-248.

Kaya, Şennur, Tanzimat'tan Günümüze İmit Kenti, Kocaeli Büyükşehir Belediyesi Kültür Yayınları, Kocaeli, 2009.

Lourenço, Paulo B., Proceedings of Historical Constructions, P.B.Lourenço, and P.Roca eds. Analysis of Historical Constructions: From Thrust Line to Advanced Simulations, Guimaraes, Portugal, 2001, pp.91-116.

Öztüre, Avni, Nicomedia Yöresindeki Yeni Bulgularla İzmit Tarihi, İstanbul, 1981.

Roca, Pere, Cervera, Miguel, Gariup, Giuseppe, Pelà, Luca. Structural Analysis of Masonry Historical Constructions. Classical and Advanced Approaches. Archives of Computational Methods in Engineering. 2010, 17. 299-325.

10.1007/s11831-010-9046-1.

Spodek, Jonathan, Rosina, Elisabetta. Application of Infrared Thermography to Historic Building Investigation, Journal of Architectural Conservation, 2009, Volume 15(1): 6581.

Tarihi Yapılar İçin Deprem Risklerinin Yönetimi Kılavuzu (TYIDRYK). https://www.ipkb.gov.tr/e-kutuphane/tarihi-yapilar-icin-deprem-risklerinin-yonetimikilavuzu_111/ Erişim tarihi: 18.05.2020)

Toker, Saadet ve Ünay, Ali İhsan. Kemerli Taş Köprülerin Matematiksel Modellenmesi ve Sonlu Elemanlar Yöntemiyle Analizi. Gazi Üniversitesi Fen Bilimleri Dergisi, 2004, 17 (2), pp. 129 - 139.

TS - 498, Yapı Elemanlarının Boyutlandırılmasında Alınacak Yüklerin Hesap Değerleri, 1987.

Türkiye Bina Deprem Yönetmeliği (TBDY), T.C. Resmî Gazete, 2018. 
URL - 1 Kocaeli Kültür Varlıkları Koruma Bölge Kurulu Müdürlüğü, tescilli yapılar listesi https://korumakurullari.ktb.gov.tr/TR-130691/tescilli-yapilar.html (Erişim Tarihi: 18.05.2020)

URL - 2 İzmit Tarihi- History of Izmit [Nicomedia], Yeni Hamam

https://www.facebook.com/groups/196704713815692/?post_id=1003163579836464

(Erişim tarihi: 18.05.2020)

URL - 3 Afet ve Acil Durum Başkanlığı, Türkiye Ulusal Kuvvetli Yer Hareketi Veri Tabanı http://kyhdata.deprem.gov.tr/ (Erişim tarihi: 18.08.2016) 